\title{
A FANTÁSTICA FILOSOFIA GREGA CLÁSSICA DOS SÉCULOS VIII-V A.C. A GRÉCIA E OS MOSTEIROS. O SURGIMENTO DO DIREITO
}

\author{
THE FANTASTIC GREEK CLASSIC PHILOSOPHY IN VIII-V B.C. CENTURIES. THE GREECE AND
}

THE MONASTERY, THE RESURFACE OF THE LAW

Antonio Augusto Machado de Campos Neto*

"Havia, a principio, três espécies de homens e não duas, como atualmente: macho e fêmea. O terceiro era formado dos dois primeiros (...) chamavam-se andróginos (...)"

Platão (428 a.C. - 348 a.C.)

“(...) o homem é naturalmente um animal político, destinado a viver em sociedade (...)"

Aristóteles (384 a.C. - 322 a.C.)

“(...) o poder de bem aquilatar e diferenciar o verdadeiro do falso, quer dizer, o chamado bomsenso ou a Razão, é naturalmente igual em todos os homens (...)

René Descartes (1596-1650)

"A virtude tem por prêmio a própria virtude"

(Sêneca in "De vita beata", 9,4)

"Sem sombra de dúvida, qualquer homem ou mulher pode realizar o que realizei, desde que faça o mesmo esforço e cultive a mesma esperança e Fé" Mohandas Karamchandi Gandhi (um dos mais fascinantes personagens da História da Humanidade)

"A poesia é também uma forma de conhecimento, tão legítima como a Filosofia ou a Ciência mais próxima daquela do que esta"

Miguel Reale

(Filósofo, Professor Emérito desta Academia de Direito da Universidade de São Paulo)

Ex-Chefe do Serviço Técnico de Imprensa e Propaganda da Faculdade de Direito da Universidade de São Paulo. Bacharel em Direito pela Faculdade de Direito da Universidade de São Paulo. Bacharel em Jornalismo pela Faculdade de Comunicação Social Cásper Líbero. Dedico este artigo a Leonidas Jean Balabakis, ex-colega, amigo querido e sucessor no Serviço Técnico de Imprensa e Propaganda. 


\title{
Resumo:
}

Não há precisão alguma ou correta na História da Humanidade do início da História do Pensamento, no intuito do saber a origem de todas as coisas. As tentativas nasceram por meio da filosofia, palavra grega que se traduz por Amor ao Conhecimento. O fio inicial da mediação que se indaga há séculos parte de grupo de pensadores dos séculos VI a.C. e V a.C., como Sócrates, da Grécia, o indiano Buda e do chinês Lao-tsé. Entrementes, nascidos na civilização helênica, surge os primeiros filósofos autores de fantástica filosofia elaborada por Tales, Anaximandro e Anaxímenes, denominados "Trio da Jônia" e classificados pela autoridade de Aristóteles de "os pré-socráticos" por terem vindo antes de Sócrates, no final do século VII a.C., e meados do século VI a.C. Do conjunto dos seus pensamentos, restaram interpretações formuladas por outros filósofos que passaram a estudar os ensinamentos da Academia criada por eles, a Escola de Mileto. Mais tarde, fins do século VI a.C., o pensamento filosófico se transfere da Jônia para a Magna Grécia, composto por grupo de pitagóricos. Mais adiante, explosivo leque de sabedoria: os sofistas e a relativização da verdade, culminando em Sócrates - o homem das indagações -, Platão, Pitágoras e Aristóteles. Participam do elenco Parmênides, Zenão de Eleia, Heráclito, Anaxágoras, Demócrito, Protágoras e Górgias. Os seguidores de uma Religião desejam seguir o código moral de sua fé, ou ética, o máximo possível, além de incluir instruções sobre observância de princípios; a Religião ensina o respeito ao próximo e a ajudar os necessitados. Dada a turbulência religiosa desta época antiga, um grupo de homens decide abandonar as cidades e a se refugiar em montanhas gregas desenhadas pelas erupções vulcânicas, surgindo os mais belos mosteiros da História da Civilização, a maioria localizada em montanhas das mais altas nas terras gregas. Não há refutação de que a Grécia nos presenteia ao orgulho de se fazer parte da Humanidade, na importância da Ciência do Conhecimento trazida ao homem moderno como ao convite de se visitá-la... antes de morrer!

Palavras-chave: Os primeiros filósofos. Os sofistas. Os belos mosteiros gregos. O surgimento do Direito e a colaboração democrática grega.

\begin{abstract}
:
There is no certain or correct precision in the history of manking about the beginnings of the history of thought, in order to know the origin of all things. The attempts were born through philosophy, a Greek word that means love to knowledge. The initial thread of mediation that has been asked for centuries is part of a group of thinkers from the VI and V. BC, such as the Greek Socrates, the Indian Buddha and the Chinese Lao-tzu. Meanwhile, Tales, Anaximander and Anaximenes, known as "Trio of the Ionia" and classified by the authority of Aristotle as "the pre-Socratics" for having come before Socrates, in the end of the seventh century BC and the middle of the sixth century BC, arose in the Hellenic civilization as the first philosophers of this fantastic philosophy. Just a few interpretations formulated by other philosophers that studied the teachings of the Academy created by them, the School of Miletus remained. Later, towards the end of the sixth century $\mathrm{BC}$, the philosophical thought was transferred from the Ionia to "Magna Graecia", composed of Pythagoreans. So an explosive range of wisdom occurred: the sophists and the relativization of truth, culminating in Socrates - the man of inquiry -, Plato, Pythagoras, and Aristotle. Parmenides, Zeno of Elea, Heraclito, Anaxagoras, Democritus, Protagoras and
\end{abstract}




\begin{abstract}
Gorgias participated in the cast. Followers of a religious wish to follow the moral code of their faith, or ethics, as much as possible, besides including instructions on observance of principles; Religion teaches respect for others and helps those who need them. Given the religious turbulence of this ancient time, a group of men decide to leave the cities and take refuge in Greek mountains designed by the volcanic eruptions, which become the most beautiful monasteries of the History of Civilization, most of them located in the highest mountains in the Greek lands. There is no rebuttal that Greece gives us the pride of being part of mankind, the importance of the science of knowledge brought to modern man as the invitation to visit it ... before dying!
\end{abstract}

Keywords: The first philosophers. The Sophists. The beautiful Greek monasteries. The emergence of Law and the Greek democratic collaboration.

\title{
I. A Clássica Filosofia grega \\ 1. Introdução
}

Por meio da Razão, certos homens da Grécia antiga procuraram satisfazêla e nessa tentativa ampliaram o conhecimento do Universo ao longo dos séculos no descobrimento da Filosofia, Matemática, Astronomia, Sociologia, Economia, Ética, Direito e Religião. Esses homens abandonaram a assertiva de que os deuses eram os responsáveis tanto na Vida quanto nos fenômenos que a constituíam na busca de respostas neles mesmos. Eles formaram a criação do que atualmente se entende por Filosofia, cujo significado, originário grego, quer dizer Amor ao Conhecimento. Os gregos contribuíram à Historia da Humanidade o lado maiêutico de como explicar o Universo e o por quê se está neste planeta: utilizaram-se da Filosofia e da Ciência. E é dificultoso contemplar qual o instante que se iniciou a História do Pensamento.

Todavia, cientistas, pesquisadores e pensadores elegeram os séculos VI a.C. e V a.C. como ponto de partida ao período comprobatório de homens pensadores - como os gregos - destacando-se Sócrates, seguido do indiano Buda e do chinês Lao Tsé. Tratase do período em que os deuses são eliminados na sua performance e na origem de todas as coisas, dando margem ao raciocínio, o qual passa a ocupar o espaço que era destinado ao mito. Enquanto os gregos - na tentativa da descoberta do que é o homem -, no Oriente a cena era outra: em 4000 a.C., os assírios e os caldeus direcionavam o raciocínio no sentido de se sistematizar as doutrinas até então conhecidas, uma vez a primeira escrita de que se tem conhecimento é de origem suméria, nascida, portanto, na Ásia em uma Região situada entre os rios Tigre e Eufrates (atualmente parte da Turquia e do Irã). Essa visão do mundo atinge o período de Zoroastro, conhecido também como Zaratustra, que propõe a adoração a um Deus Único e a realização de uma reforma no âmbito da Religião, século VIII a.C., na Pérsia (atual Irã). 
Zaratustra ensinava a existência de um Deus Único, entre a encruzilhada do Bem (luz), Ahura Mazda e o do Mal (escuridão), chamado Arimã. A escolha, livre arbítrio, caberia a cada um de nós quanto ao discernimento nesta busca de mais ordem, progresso e maior grau de abstração. Em 1500 a.C., a coleção de obras em sânscrito, os Livros dos Vedas que exibiam hinos épicos, a exemplo do Rigueda e deles extraídas ideias magníficas como a existência de uma Ordem no Universo, por meio dos níveis físico (Pita) e moral (Dharma). Os brâmanes pertencentes à Literatura védica são livros de suma importância que auxiliam a compreensão da evolução doutrinária na Índia antiga, preenchendo um período que chega a 850 a.C.

No século XVI a.C., na China, a ideia de que o Universo é regido por forças extraterrenas, cabendo ao imperador a intermediação entre Shang-Ti, divindade celeste, e o homem, sendo que a felicidade depende da sabedoria do soberano e das consultas preliminares ao I Ching, o Livro das Mutações; ensinava que em cada situação ou em cada ato, duas forças opostas sempre atuavam, a saber: o Yin e o Yang. Como exemplo, luz/trevas; certo/errado; ação/reação inerentes à Natureza e ao homem. Dessas ideias, duas correntes que, por sua vez, têm raízes na tradição chinesa: Confucionismo (fundada por Confúcio (551-479 a.C.) e o Taoismo que tem como filosofia o desprezo aos valores sociais, à família e ao Governo, cuja pregação era liderada por Lao-tsé ("Velho Mestre") que viveu em 604-531 a.C., Autor de Tao Te Ching, Livro do Sentido da Vida que narra do indefinível, Tao, que é concomitantemente meta e caminho a ser seguido de maneira transcendental.

Todavia, a maneira nova de se pensar (cogito $=$ penso, $\operatorname{logo}$ existo $)$ e a de se conceber o Universo é originária da Grécia clássica, na época constituída de pequenas tribos comunitárias, independentes e espalhadas desde a Jônia (Ásia Menor) ao Sul da Itália, Sicília/Siracusa, junto ao Mediterrâneo. Ao centro, a Grécia antiga, formada por grupos de homens que falavam o mesmo idioma, vida cultural homogênea com organização política e crenças religiosas, a civilização helênica. A esta civilização, vários grupos de outras regiões invadem seus territórios e a se agregar na busca de terras férteis ao cultivo e à pastagem de animais, acarretando fusão de várias culturas a quem o poeta Homero os denominou aqueus. A prosperidade chega pelo conjunto desses blocos heterogêneos e povo guerreiro; construíram enormes fortificações, surgindo vilarejos como Pilos, Tirinto e Micenas; todavia, guerreavam entre si, sendo Micenas a vencedora dessas lutas internas que, por sua vez, irradia por toda a Grécia o seu peculiar modo de vida, porque a sociedade micênica tinha o perfil de organização extremamente hierarquizada ao redor da aristocracia e da família real. Os micenas eram exímios comerciantes, enriquecidos, inclusive, por meio da pilhagem de guerra. A expansão micênica abrangia Troia, Sicília, Península itálica e o Ocidente. 
Em 1150 a.C., os dórios invadem a Grécia, vindos do Norte europeu e se estabelecendo em Epiro, Acarcânia, Etólia, Peloponeso, Creta e Anatólia. Mas não foram os únicos; outros povos como os beócios, tessálios e trácios invadem, também, as terras gregas e a própria Micenas é destruída, com saldo negativo ao comércio que se torna retrógrado, restando forte queda à atividade agrícola. No mesmo espaço de tempo, a escrita desaparece, surgindo somente no século IX a.C. Esse período chega ao século VIII a.C., sendo classificado pelos historiadores de Idade das Trevas: as tribos se tornam isoladas, não há harmonia entre os membros da aristocracia e estes se afastam da população pobre. Mas, na metade do século VIII a.C., renasce o comércio, cujo impulso vem com a invenção da moeda cunhada; porém, a sociedade se torna mais complexa, deixando de ser um aglomerado de agricultores, artesãos e comerciantes que transformam o perfil arquitetônico do centro da cidade. Eles trabalham em torno do Palácio central que faz nascer a ágora: a praça pública. Neste espaço físico, as reuniões, notadamente ao início do entardecer, onde discutiam a vida social, o progresso e a defesa da cidade, a ágora se torna cada vez maior, surgindo, assim, a instituição Democracia; estrangeiros e escravos não podiam participar desses encontros. A permanência na ágora era expressamente proibida às mulheres e crianças, ou seja, a permissão era somente aos homens adultos.

Desta especificidade organizacional e político-social a criação da pólis, lugar onde se expressava, por meio de discursos, a Política que deixa de ser privilégio dos ricos, donos de terras e do monopólio local, dando margem à elaboração das Leis - que mais tarde passam a ser escritas - junto à Religião, instituição rejeitada ao saber único e secreto dos Reis e sacerdotes, contribuindo à evolução do pensamento humano, por meio da Razão, da exposição de motivos, convencendo todos os membros conterrâneos. Enfim, o século VIII a.C., na Grécia, fez com que o cidadão se libertasse das fantásticas histórias da Mitologia e da Religião para se afirmar e a se desenvolver, em torno da Razão das coisas. Nesse contexto, o seu maior representante: Homero.

Cumpre salientar que, na época de Homero - antes do nascimento da pólis -, a vida cultural na Grécia era extraordinária em áreas como as artísticas e matemáticocientíficas. Homero foi Autor de poemas que narram as guerras de Troia entre 1260 e 1250 a.C., como as Ilíadas que serviram de parâmetro às filmagens modernas, mostrando o desempenho do grego Aquiles, guerreiro envolvido em aventuras contra os troianos, além do épico Odisseia sobre o herói Ulisses na longa viagem - após a derrota de Troia -, para Itaca, onde nasceu e o encontro com a bela Penélope, sua amada esposa que há vinte anos o esperava. Após jornada de guerra marítima, perdendo sua frota e seus homens, Ulisses retoma o trono perdido.

Tanto as Ilíadas quanto a Odisseia narram histórias dos deuses locais, além de mitos e lendas; todavia, não contêm narrativas dos povos em guerra mas, sim, sobre os dórios - vindos do Norte europeu -, após as guerras troianas que instituíram ao longo 
dos séculos uma sociedade aristocrática, vindo a ser a futura civilização genuína grega ou helênica. Homero escreve fatos em tempo bem anterior ao seu como, também, suas obras se fizeram conhecidas em período posterior à sua vivência na Grécia. Os poemas chegam à Atenas no século V a.C., um mundo completamente diferente do período homérico: num espaço de tempo em que a sociedade aristocrática era versada ao luxo, beleza e fantasia, integrantes do regime democrático. Homero não deixou de ser contemplado como o Pai da Cultura Helênica, consagrando a inspiração de não mais se recorrer aos deuses que, por sua vez, abandonaram os homens às ideias ocidentais no século VII a.C., e baseada, também, por meio da obra do poeta Hesíodo, intitulada Teogonia, na qual descreve a criação do Universo e dos deuses, a partir de Caos, Gaia ou Terra e de Eros (deus do Amor). Narra outras divindades em suas mentiras e traições até finalmente à vitória de Zeus, onde se instalam, no Monte Olimpo. ${ }^{1}$

Entre os séculos VIII e V a.C., empreende-se a busca pela construção de uma sociedade justa, de pensamento racional e totalmente extirpada a mente de preconceitos, originando a Democracia e a Filosofia. Entremeio, século VI a.C., novo modo de pensar $(\operatorname{cogito}=$ penso $)$ racional e filosófico, considerado o oposto ao pensar mítico como se tivesse libertado da Mitologia e da Religião e ao caminho da evolução racionalista. A Religião, neste período homérico, classifica-se totalmente frágil em fundamentos e se torna pouco eficiente como instrumento de Poder, porque a ideia do Rei divino se apaga, fortalecendo a Política e o Governo que, por sua vez, se tornam referência de estudos de doutrinas em assuntos e atividades mais humanos.

Por outro lado, a Grécia antiga ainda não alcança o estágio de Império, torna-se dominante de várias regiões e nelas o surgimento de comunidades. Estas, se tornam cidades, dando alicerce às construções de Estados-gregos que têm em suas unidades organização independente, emergindo Atenas em sua plenitude. Desse ineditismo,

Grande parte de historiadores e jornalistas acredita que toda lenda e mito têm um fundo de verdade; nesse ínterim dizia-se que Zeus e os outros doze deuses e deusas mais importantes viviam no topo do Monte Olimpo, a montanha mais alta da Grécia e cada divindade se apresentava como um aspecto da vida terrena; por exemplo, Afrodite era a deusa do Amor, Hefaístos, deus do Artesanato e Ares, deus da Guerra. Segundo Hesíodo, após a vitória das lutas enfrentadas por Zeus, o homem torna-se livre das cruéis maquinações dos demais deuses. Por meio de Zeus nasce a Justiça e a Lei do Amor. Em sua obra "Os Trabalhos e os Dias", escrito com o propósito de pedir a punição de um irmão desonesto, Hesíodo defende a necessidade do trabalho árduo como condição humana. O Ser humano, segundo ele, teria passado por cinco etapas de vida: a idade do ouro, a da prata, a do bronze, a dos semideuses e a do ferro. Na primeira etapa, idade do ouro, existia convivência com os deuses, quando não se conhecia o trabalho, tampouco a morte. Na idade do ferro, após a passagem em brancas nuvens da intermediária, o homem - após ter recebido o fogo roubado de Prometeu - foi separado dos deuses como, também, condenado a trabalhar e a procriar sem a interferência dos deuses. Ressalta-se que a procriação é permitida por Pandora, a mulher enviada pelos deuses como revanche pelo fogo roubado e por meio dela ou da caixa que carregava, na qual no seu recinto os males da Terra, uma vez o homem estar abandonado pelos deuses; todavia, livre para corroborar à valoração da Justiça e também livre para raciocinar de acordo com o seu próprio livre arbítrio e discernimento. 
o desenvolvimento de maneira sistemática e nova do Pensar e o da Política aflorada em ambiente inovado junto ao nascimento de conceitos que formam a Filosofia pura e ocidental, propriamente correta, além da construção da ideia de que a soberania é da Lei e não de Reis, deuses e deusas; a soberania emana da vontade do povo. Um período contemplado por Demócrito, Homero e Hesíodo ressurgido como a fênix da Idade das Trevas. O conjunto de Estados-gregos é favorecido pelo surgimento de novos valores sociais e pela iniciativa dos cidadãos que os compõem. A cidade de Mileto desponta gloriosa no centro da Jônia e nela a manifestação dos primeiros filósofos como Tales, Anaximandro e Anaxímenes, classificados pelos historiadores de "os pré-socráticos" por terem surgido antes de Sócrates.

\section{O surgimento dos primeiros filósofos}

Os historiadores e escritores gregos classificam Tales como o primeiro filósofo (final do século VII... século VI a.C.). Para Tales, nascido em Mileto, no Universo tudo começa na água. As suas especialidades eram a Astronomia (previu o eclipse do Sol, em 585 a.C.) e a Matemática. Segundo o filósofo, a água, ao se esfriar, torna-se densa, dando, assim, origem à Terra. A água ao se aquecer, se transforma em vapor e ar que, por sua vez, retornam como águas de chuva, quando novamente esfriados. Antigos relatos the atribuem qualidades que o destacam na Engenharia, Economia, Astronomia e Política, cujo perfil é o de um homem de uma cultura que excede o comum. Pouca coisa é registrada a seu favor; todavia, só o fato de ser um pensador na busca da origem ou princípio das coisas, o colocam no patamar de se poder aquilatar o seu valor. Tales é o primeiro do Trio Jônico que instituiu a Escola Jônica ou Escola de Mileto, cuja metódica serviu a envolver todo o interesse do conhecimento que era a da procura do princípio e fundamento das coisas em sua possível abrangência.

A única fonte de informação que se tem sobre o gênio Tales vem da autoridade de Aristóteles, que o classifica como o primeiro dos filósofos, principalmente pela assertiva de que o primeiro e fundamental elemento da origem das coisas é a água, provavelmente porque Tales sabia que onde há água, há vida e sem água não há vida. Tales deve ter lido a Bíblia e nela visto que no princípio a água cobria toda a Terra e o Espírito de Deus pairava sobre as águas. Essa informação cosmogênica, com certeza, era de seu conhecimento e nela sério fundamento científico. Tales, além de exímia cultura adquirida, era pesquisador e se valeu do seu melhor saber para tecer a sua filosofia.

Anaximandro é o segundo do Trio Jônico, discípulo de Tales. Ele foi diretor da Escola de Mileto, em meados do século VI a.C., sucedendo Tales. A sua obra conhecida sob o título Sobre a Natureza foi, infelizmente, perdida. Nada se sabe sobre a vida de Anaximandro; todavia, atribui-se-lhe diversos inventos - características dos 
antigos gregos -, enquadrados na Matemática e Astronomia. Ele apontou o princípio das coisas intitulando-o Apeiron, palavra grega que se traduz por algo indeterminado, grandioso e ilimitado. Esse Apeiron, como princípio, é o elemento fundamental do qual se constituiu o que existe, chamado Natureza: o conjunto de todas as coisas; em síntese, algo indeterminado e grandioso de onde tudo emerge. O por que de que umas coisas chegam a ser e outras deixam de ser, permanecendo independentes e superiores às mudanças individuais, isto é, os contrários ou inversos de uns sobre os outros. Exemplo: o frio sobre o quente, o úmido sobre o seco, a geração e a morte; enfim, movimento que produz injustiças. Mas o tempo fará com que todas as coisas regressem ao Apeiron, à unidade ou a essa quietude e indeterminação de onde saíram injustamente. A acuidade do pensamento de Anaximandro conduziu à passagem de simples designação de uma substância - como princípio -, para a ideia de Natureza que, por sua vez, é o conjunto de todas as coisas. E que vai ser em Aristóteles o princípio do movimento. Em premissa final, o Apeiron, além de indeterminado é imperecível e alheio à mutação e à pluralidade. O oposto à variabilidade das coisas.

Anaxímenes, discípulo de Anaximandro, é o último dos três jônios, também nascido em Mileto na segunda metade para o fim do século VI a.C. Para ele, o princípio e fundamento de todas as coisas é o $a r$, elemento indispensável à vida, relacionando o princípio por meio da respiração. Para o filósofo Anaxímenes, sem ar ou sem oxigênio a vida não existe e deduziu que as coisas são formadas pela via aérea, por meio da condensação e rarefação, sendo que o ar rarefeito é fogo; mais condensado é nuvem, água, terra, segundo o grau de densidade. À substância fundamental se agrega o movimento e, assim, se produz a variedade mutável das coisas. Anaxímenes não-só posiciona um princípio como fundamento das coisas como, também, apresenta a forma e o processo pelo qual - a partir dele -, as coisas surgem ou nascem.

\section{A Escola itálica}

Nos fins do século VI a.C., o pensamento filosófico se transfere da Jônia à Magna Grécia, ao Sul da Itália, constituído por grupo de pitagóricos, surgindo a Escola itálica - designação dada por Aristóteles -, que teve a participação de Pitágoras. ${ }^{2}$

2 Conforme afirmado acima, nada se sabe corretamente sobre Pitágoras, principalmente quanto à sua intelectualidade fora de série. Mas existe um conto ou lenda na História grega de que Partner, mulher de Mnesarcos era a mais bela de Somos e de que ele fora escolhido por Apolo para nela gerar um semideus. A fecundação se deu com grande satisfação de Mnesarcos que se sentiu enobrecido pela escolha da sua mulher. E dela nasceu Pitágoras que se tornou tão belo como a um deus e à sua mãe. Um deus sábio, inteligente, desvanecido e repleto de vaidade. Mnesarcos, ao verificar a beleza masculina de Pitágoras, mandou erigir um templo em agradecimento e homenagem ao deus Apolo. A beleza masculina de Pitágoras é assemelhada a de Alexandre da Macedônia! 
Na verdade, nada se sabe sobre Pitágoras; todavia, é o grande filósofo grego a quem ocorreu - pela primeira vez -, a ideia de que o princípio de onde tudo se deriva ou do que tudo emerge ou, ainda, aquilo que existe de verdade, o verdadeiro Ser - ou Ser em si - , não é uma coisa formal, porém algo que não é sensível aos sentidos. Pitágoras descobriu um tipo de entes que não é corpóreo, mas que possui realidade e oferece resistência ao pensamento. É o número! O número é a essência única das coisas que se percebe pelos sentidos em sua representação fenomênica, uma vez as coisas são distintas umas das outras pela quantidade numérica. O número é a força maior, soberana e autógena que, por sua vez, mantém a permanência eterna de todas as coisas cósmicas. Essa força maior e soberana é o Poder Supremo que gera a si mesmo e mantém a eternidade. Premissa final: o número é a própria essência do Cosmos.

O número $U m$ é ímpar e sugere a ideia do Dois: o par. São os pontos que estabelecem o movimento reto, a reta, a linha reta. O número Três representa o triângulo e realiza a superfície e o espaço físico e sugere a ideia da Trindade da Criação: Deus, Espírito e Matéria. O número Quatro simboliza a realidade temporal, a dimensão dos eventos e com eles a própria Vida, a temporalidade das vivências da experiência, da realidade sensível. Premissa final: a soma desses números chega ao Dez: o número soberano e simbólico que nos lança no infinito.

Por fim, o número Um, a unidade, é o Princípio de Todas as Coisas. Tudo começa pela unidade: Deus. Ele é Único e o primeiro entre todas as coisas; a Unidade Primária, Causa infinita do processo infinito das causas e dos efeitos finitos. O Universo é a unidade, constituída pela multiplicidade. E assim, os pitagóricos descobrem um tipo de entes; traduzindo, os números e as figuras geométricas não são corporais, mas possuem aquela realidade que oferece resistência ao pensamento. Isso conduz a pensar que não é lícita a identificação imediata do Ser com o Ser corporal por implicar uma ampliação da noção de entes de forma decisiva. Finalizando Pitágoras, ele trouxe à Música robusta colaboração, uma vez ter relacionado o som de cada corda da Lira com o comprimento e espessura de cada uma, iniciando a identificação da frequência vibratória com o som musical.

\section{Parmênides, Zenão de Eleia e Heráclito}

Parmênides nasceu na pequena cidade de Eleia e é o mais importante filósofo dentre os pré-socráticos. Cumpre salientar que, antes deles, a Filosofia era física e por meio deles torna-se metafísica. Anteriormente à Era cosmológica se buscava o fundamento das coisas; com Parmênides torna-se ontológica (Ontologia é a Ciência do Ser), uma vez a procura do saber por que as coisas são em si e é justamente neste tópico que a Filosofia registra a sua individualidade, esclarecendo, assim, quanto possível o procurado objeto: o 
Ser. A Filosofia, em sentido restrito, inicia, por meio do pensamento parmenídico, o tema central de toda a cogitação ao longo da História da Filosofia até o deste século, assumindo na Filosofia Espírita da Existência o seu auge, o ponto culminante, uma vez que em suas categorias da Razão, o Ser se identifica ao próprio Espírito, fora do tempo e do espaço.

Recorda-se que o Espírito é a verdadeira coisa em si, abstrata, metafísica que aparece realizado no mundo corporal e no mundo espiritual. A sua composição se constitui de Espírito e corpo físico no plano terreno. No espiritual ou energético, o mesmo Ser aparece como Espírito e o envólucro perispiritual energético, adequado e próprio às suas manifestações de Ser racional, ou seja, Ser indivíduo.

Segundo Parmênides, as coisas (pragmata, em grego) revelam aos sentidos propriedades múltiplas, porque são seres animados e inanimados, coloridos, grandes ou pequenos; e elas podem ser feitas pelo homem ou originárias da Natureza, estas criadas pelo Deus Único. Todavia, consideradas exclusivamente pelo pensamento que apresenta um atributo fundamental comum a todas as outras coisas. Antes de outra qualidade, simplesmente são, existem, têm existência, Ser; enfim, são entes que têm o Ser. Desta maneira, o Ser aparece como propriedade especial que, mais tarde, foi chamado Predicado Real: que não se manifesta aos sentidos, mas somente ao pensamento, levando Parmênides à enumeração da existência de dois mundos:

* o mundo da verdade e

* o mundo da aparência, isto é, o mundo sensível e o inteligível.

A sua classificação sobre o Ser é extraordinária: Único, Eterno, Infinito, Imutável e Imóvel.

* Único, porque só pode haver um Ser. Se houvesse dois, aquilo que os distinguiria um do outro estaria em um e não estaria no outro. O nãoestar traz a ideia do não-Ser; estariam diferenciados pelo não-Ser, ou seja, por algo que não é; pelo nada e o nada não existe.

* Eterno, porque se não fosse eterno, teria sido princípio e assim teria um fim pela lógica das coisas. Nesse ínterim vem a imemorável pergunta: o que é que existia antes do Ser e o que o substituirá depois dele? A resposta parmenídica: seria o nada, isto é, o não-Ser.

* Imutável, porque mudar é deixar de ser o que é, para ser o que não é. Nessa mudança o Ser se transmuda para o não-Ser, para o nada e isso é impossível, já que as coisas mudam, se transformam, mas o Ser é imutável e o Ser mantém a estrutura abstrata das coisas que, por sinal, do ponto de vista metafísico são sempre. Por fim,

* Imóvel, porque o Ser açambarca tudo o que existe e nada pode ficar fora dele, uma vez que não há nada que o Ser não esteja. O Ser é realidade 
existencial de tudo quanto existe e, assim, não há realidade vazia para onde possa caminhar.

Para Parmênides, ${ }^{3}$ o Ser é a unidade em que se ramifica a multiplicidade universal; para ele, obtendo solução ao problema, conclui-se pela existência do mundo da verdade, que é o inteligível e o mundo sensível, ilusório - o dos sentidos -, que nos enganam e falseiam a verdade!

\section{O Realismo Metafísico}

O historiador e filósofo Garcia Morente nos relata sobre o pensamento de determinado grupo de filósofos de várias nacionalidades, desta época moderna, que se reunia ao redor do professor de Filosofia Hermann Cohen em Hamburgo, Alemanha, os quais em debates semanais deduziram que as ideias de Parmênides e de Platão têm de ser catalogadas como precursoras do Idealismo. O historiador Morente demonstra, também, que esses dois filósofos gregos são indubitável e eminentemente realistas; todavia, o seu pensamento se expressa semelhantemente desta maneira:

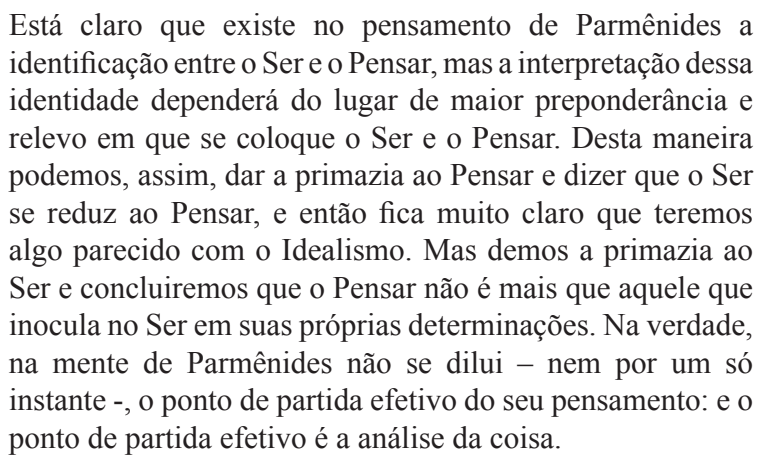

Parmênides parte metafisicamente da realidade das coisas, de que as coisas são reais; de que as coisas que captamos pelos sentidos possuem, por sua vez, a plenitude do Ser. Porém, pergunta imediatamente à si mesmo:

* em que consiste esse Ser das coisas?

3 Sobre Parmênides quase nada se sabe, a não ser que viveu nos fins do século VI a.C., e na primeira metade do século V a.C. Todavia, Platão lhe dedicou um de seus "Diálogos", o qual leva o nome de "Parmênides", considerando-o o mais importante de todos os filósofos daquela época. Aristóteles se ocupou amplamente de sua filosofia, abrindo uma fenda no envólucro hermético em que Parmênides colocou o Ser e se vai relacionar com ele nas várias formas analógicas que o próprio Aristóteles descobriu. Também sobre Parmênides é conservado fragmentos notáveis de um poema em hexâmetros, versos alexandrinos, cujo título é "Sobre a Natureza" em duas partes: a primeira parte do poema compreende uma introdução de grande força poética e a segunda parte é dividida em dois temas intitulados "Via da Verdade" e "Via da Opinião"! 
* como podemos Pensar esse Ser sem contradição?

* como podemos ajustar o nosso pensamento a esse Ser?

* como identificá-lo com o Ser?

Resposta: analisando as coisas, livrando-as de tudo aquilo que tiverem de contrário às condições do pensar. Uma das condições lógicas de todo o pensamento é que ele concorde consigo mesmo, que seja coerente, que não seja contraditório.

Premissa final: em suma, que não afirme uma coisa, e logo depois também o seu contrário. Uma coisa não pode Ser e não-Ser ao mesmo tempo. Mais tarde - como norma de uma vida moral -, portanto, intimamente confortável, Jesus Cristo aconselharia: 'Seja o Vosso Dizer Sim, Sim, Não, Não'

Para Parmênides, a realidade continua a ser uma coisa que não admite outra ao seu lado, porque seria contraditório; não admite mudança, porque seria contraditória. Contudo, o primeiramente existente é res=coisa; por isso, diz o filósofo Morente "eu me atrevo a dizer que Parmênides é, na realidade, o primeiro fundador do Realismo Metafísico, embora na expressão isto resulte em paradoxo”.

\section{Zenão de Eleia}

Zenão também viveu na pequena cidade grega de Eleia entre 490 a.C. e 430 a.C. Discípulo de Parmênides, sua filosofia é concentrada no esforço nítido, procurando justificar a imobilidade. Justificado o movimento não existe, porque o Ser é imóvel e a sua explicação comprobatória da inexistência do movimento se baseia em princípios lógicos, isto é, apelos à razão.

Na elaboração da sua teoria se embasa no exemplo de uma competição entre Achilles e uma tartaruga. O grande corredor de maratona não alcançará a tartaruga se no começo se der alguma vantagem à tartaruga. Achilles jamais alcançará a lenta tartaruga e oferece as razões:

O espaço é divisível ao infinito; desta maneira, para passar de um ponto a outro em razão da infinita divisibilidade é necessário um tempo igualmente infinito. E nesse tópico se coloca um filosofema sem soluções. Aquilo que não se pode pensar não existe, porque tudo o que existe é racional. E o que não é racional não existe; assim, o movimento não existe, porque não se pode pensar em uma divisão infinita em tempo e em espaço.

Premissa final: não se trata de um sofisma, mas de uma forma correlata em relação ao pensamento e o Ser, uma vez o próprio Parmênides haver sintetizado a ideia da identidade entre o Ser e o Pensar. Ser e Pensar são a mesma coisa! 


\section{Heráclito e Anaxágoras}

Pertencente a uma família real de Éfeso (Sul da Turquia), Heráclito viveu entre os séculos VI e V a.C. Ele fora chamado a administrar a sua cidade; todavia, renunciou ao cargo para se dedicar à Filosofia muito em voga em sua época. Heráclito se opõe a Parmênides na assertiva “o movimento rege os fenômenos da Natureza”. E toda a sua filosofia consiste em demonstrar que a dialética da Natureza mostra a multiplicidade e a variabilidade das coisas; muito ao contrário do Ser de Parmênides que exclui taxativamente o movimento. As coisas são em definitivo; todavia, estão em contínua e constante transformação. A Lei é o fluir, é a inconstância a gerar o devir; a instabilidade é permanente.

Heráclito chega a pronunciar que "nunca nos banhamos mais de uma vez nas águas do mesmo rio; mesmo que ele ali permaneça, as suas águas passam e não voltam mais. A Natureza é um germinar, de crescer, frutificar e morrer para voltar ao germe, ao fruto e à semente."

A História da Filosofia tem ressaltado essa forma do pensamento heraclitiano, porque é a que mais prontamente se oferece à aprovação do homem; contudo, Heráclito seguiu mais longe: não resumiu a sua filosofia apenas aos aspectos transitórios da Natureza. O filósofo Julian Marias, assevera em sua obra História da Filosofia que "Heráclito diz que é sensato confessar que todas as coisas são unas; por outro lado, o pensamento é comum a tudo. Estas afirmações são de um modo bem diferente, possuindo claras ressonâncias parmenídicas". E mais ainda "Heráclito introduz novo conceito a respeito do qual afirma predicados que são típicos da filosofia de Parmênides. Este conceito é do sábio”. Mais à frente retorna a Heráclito que vai apresentar a assertiva máxima: "Os que velam têm um mundo comum; mas os que dormem regressam ao seu mundo particular".

Heráclito foi um filósofo que se deve conhecer como o pensador mais positivo e não como curiosidade extraída do mundo dos sentidos. E se assim não fosse a História da Filosofia não teria se ocupado dele, uma vez que sua obra afirma a Natureza das coisas, cuja multiplicidade não-só ressalta como, também, sintetiza a unidade universal, fácil de constatar e apartar em sua autenticidade, isto é, sem confundir com a unidade que tudo liga a uma ideia soberana. Mesmo porque o Ser está em cada coisa, enquanto é e a faz ser.

Premissa final: é difícil de se compreender de imediato, mas a Filosofia é Ciência perene: está para o Espírito tanto quanto o Espírito está para o Ser, fora do tempo e do espaço!

O Ser humano, como coisa do mundo, está sujeito ao devir, mas possui algo de comum a todos os seres, de semelhante e de imagem como criatura - o Ser Criado - 
tendente para a sabedoria divina, na qual se realiza como obra do Pai Todo-Poderoso, o Deus Único. O existir é um constante devir ou vir-a-ser, cuja manifestação verdadeira irretroativa se dá ao indivíduo. E desde aquele momento em que se deu o recorte no Elemento Inteligente da Criação para se embrenhar - na força da Lei da Vida - no processo dos Reinos da Natureza e progressivamente caminhar, ascendendo por meio das várias instâncias existenciais até a racionalidade.

E a partir daí para as superiores, das quais não temos ideia alguma, a não ser nominalmente: estruturas dos anjos, dos arcanjos e dos cristos. Nada mais do que isso. O fluir existencial é apresentado por pinturas de cores fortes, que agitam o pensamento pelos ensinamentos sábios de Heráclito - opositor de Parmênides -, dando solução à variabilidade das coisas ante a unicidade e imutabilidade do Ser; porém, paralelamente se alinha à ideia central da filosofia posta por Parmênides: a do Ser com os seus atributos.

\section{Anaxágoras}

Anaxágoras era membro de família nobre composta, como o seu pai, de indivíduos - todos de nacionalidade grega - de hábitos e costumes de alto nível. Tanto assim que os membros de sua família ambicionavam atingir posição compatível com a nobreza vigente. Entretanto, Anaxágoras refutou tal empenho, entregando-se a uma vida teorética. Ele viveu no século V a.C., era homem de expressão ética, justificando, assim, tendência para a vida contemplativa. Manteve vínculo, de estreita relação, com a sofística, notadamente com Protágoras. Mas ele não era de Atenas, nasceu na Jônia, e como os atenienses não eram pródigos para aos que não pertenciam a Atenas, esse deve ter sido o motivo para que o cognominassem depreciativamente. E foi acusado por alguma causa não-explicada, isto é, sem qualquer prova, quando foi injustamente preso; porém, logo libertado por Péricles, ${ }^{4}$ que atendeu ao pedido de seu indignado pai.

Após ser libertado por Péricles, Anaxágoras não pôde continuar vivendo em Atenas. Anos mais tarde, chega-se à conclusão de que ele fora rejeitado e preso, porque afirmava que há de tudo em todas as coisas, dando o nome de homeomerias (elementos fundamentais de todas as coisas). Às partículas minúsculas, homogêneas, de que se compõem as coisas chamava de homeomerias; mesmo as partes - por mais pequenas que sejam - são feitas por homeomerias.

\footnotetext{
$4 \quad$ Péricles, estadista ateniense (490-429 a.C.), discípulo de Protágoras, Zenão e do próprio Anaxágoras. Ele se tornou chefe do Partido Popular e subiu ao poder iniciando série de profundas reformas; dentre elas, reduziu a autoridade do Areópago; determinou que os juízes fossem escalados por sorteio e admitiu testemunhas, além de ter incrementado as Letras e as Artes. A cultura ateniense foi tão esplêndida em seu tempo que o período é conhecido como o "século de Péricles", dado o florescimento cultural.
} 
A diferença entre as coisas reais são motivadas pela oposição e ordenação das homeomerias no todo do objeto. A agregação e a desagregação das coisas ocasiona ou impulsiona o movimento. O existir de tudo em todas as coisas intitula-se Pansperma. Enfim para Anaxágoras a formação das diversas coisas se realiza pelo agrupamento de partículas e, ainda, segundo a posição que assumem, é relevante em relação à forma e à sua importância que, por sua vez, caracteriza a disposição e a qualidade das coisas.

Os gregos ainda, neste período, não tinham noção da existência do Espírito, chamavam-no de nous (Espírito inteligente) que é tomado na significação de pensamento como, também, da mente. O nous é a coisa do movimento, designando a forma, empregam a palavra eidos que se encontra com frequência na linguagem filosófica; traduzindo: ideia.

Cumpre salientar que a doutrina de Anaxágoras tem um alcance que ultrapassa a que ele mesmo lhe conferiu, segundo Aristóteles e Platão. E os dois filósofos davam enorme valor à doutrina do nous, censurando Anaxágoras por usá-lo muito restritamente; unicamente para explicar o movimento das coisas. É que o nous anaxagórico, separado da matéria ou, pelo menos, nos limites dela é como que uma inteligência impessoal, nãoobstante se considerar ordenadora dos movimentos cósmicos. Inteligência impessoal é conceito moderno.

O conhecimento tem certos limites na concepção de Anaxágoras, porque as homeomerias não são acessíveis aos sentidos. Em seu pensamento ou ideia de percepção afirma que são conhecidas pelos seus contrários que, na realidade, se definem melhor por seus contrários.

\section{Demócrito. Os sofistas}

Demócrito (470-370 a.C. $)^{5}$ nasceu em Abdera, pertenceu ao grupo dos atomistas e foi discípulo de Leucipo. Tanto ao aluno quanto ao mestre, de respeitável conhecimento, o mundo é composto de átomos (átomo é uma palavra grega que significa não-divisível). O átomo é indivisível como, também, imutável, eterno, sempre idêntico

\footnotetext{
Demócrito, tendo recebido uma herança paterna em dinheiro, cerca de 500 talentos, lançou-se no mundo em busca de conhecimentos e aventuras. Ele viajou pelo Egito, Caldeia, Pérsia e em quase todas as regiões do Mar Vermelho, passando pela Etiópia e Índia. Por isso, esvaziou toda a herança dos bolsos; porém, enriquecido pela experiência viva e conhecimentos adquiridos. Mas não pôde continuar se mantendo no rumo escolhido pela falta de recursos financeiros e, assim, voltou à Abdera, sua terra natal. Todavia, uma Lei vigente lhe era desfavorável, uma vez que retirava àquele que dissipasse seus haveres, fora da pátria, o direito de nela ser sepultado. Mas antes da Lei, Demócrito já havia elaborado um tratado sobre o Sistema Cósmico e nesse caminho difícil lançou mão dele próprio: submeteu-o à apreciação de seus compatriotas mais eminentes e com honrosa deferência do Autor a tão destacada personalidade. Os compatriotas, orgulhosos ante o exímio trabalho do insigne patrício, o premiaram por meio de uma soma em talentos de autêntica moeda grega, garantindo-lhe a cidadania periclitante.
} 
a si mesmo. E nesse sentido, o equivalente ao Ser de Parmênides. Porém não é único, porque os átomos são em número infinito.

Por consequência é que entre um átomo e outro existe um algo: um vazio, um nada, um não-Ser, repudiado por Parmênides e Zenão. E é nesse vazio que os átomos se movem. Ao seu entrechoque são produzidas diversas combinações, resultando a pluralidade das coisas, ou seja, o mundo em movimento. Em premissa final: o movimento não passa de um agregado de átomos, enquanto a morte é apenas a destruição desse agrupamento, sendo que em ambos os casos cada átomo permanece intacto e imutável.

Demócrito se esmerava em tudo o que fazia, dedicando-se ao trabalho com infinito entusiasmo. Ele tinha o hábito de se exercitar por meio de reflexão filosófica como forma de práxis grega. Desde jovem costumava sair para o campo e a se dirigir aos sepulcros, junto aos quais permanecia em profundas meditações sobre os problemas e enigmas da vida e da morte.

Dada a sua serenidade, temperamento afável, sempre tranquilo e sorridente, soube conquistar e manter por toda a vida o respeito e a simpatia de seus contemporâneos. Ele morreu aos 109 anos.

Segundo o historiador grego Trásilo, as obras de Demócrito estendem-se por quinze tetralogias em extensão colossal no gênero e na época. As duas primeiras abordam a Ordem Moral, iniciado em um livro sobre Pitágoras, cujo conteúdo descreve a existência da semelhança e na oposição entre o atomista e Platão. E um dos livros apresenta ênfase à bondade e à virtude, além de possível tratado da alma, o que lhe daria precedência sobre a obra de Aristóteles numa visão do pensamento de Demócrito a respeito do assunto.

As obras físicas se iniciam por $O$ Grande Diacosmos, título de um tratado geral sobre o Universo ou Grande Sistema Cósmico. Em seguida, O Pequeno Sistema Cósmico e para finalizar, se menciona em Cosmográfica, livro sobre os planetas, além de outro intitulado Da natureza.

Enfim, uma coletânea preciosa que analisada pode apresentar sempre algo novo no pensamento grego e na Filosofia de seu tempo, uma vez em épocas remotas, o filósofo já asseverar haver muitos planetas em nossa galáxia, ao redor do sistema solar.

Para o sábio filósofo grego, tudo se constitui de átomos de maneira que o próprio pensamento não é outra coisa se não movimentos atômicos; daí a firmeza que os materialistas modernos incluem Demócrito na lista dos mais respeitados; porém, há mais complexidade do que lhes parece ... na oposição de Demócrito.

A inteligência de Demócrito era extraordinária com um quociente de inteligência (QI) fora dos parâmetros em comparação aos homens de sua época, nos fazendo crer que o gênio Demócrito se comunicava com visitantes estelares de outros planetas, portadores de conhecimentos avançados aos terrestres. Mesmo porque o próprio filósofo narrava aos compatriotas, como o historiador Hesíodo, de que ele mantinha comunicação 
com seres que habitaram a Terra há milhares de anos, incluso o período anterior à Era do Gelo. Visitantes que manipularam nossos DNAs no intuito da progressividade terrena e que talvez sejam os ancestrais da população deste planeta.

Todo o raciocínio intelectual de Demócrito veio por meio da mediunidade espiritual que possuía. Ele mesmo alegava ter comunicação com deuses e deusas que, segundo ele, transmitiam-lhe à sua vivência terrena por meio de ideias jamais organizadas anteriormente. Ou seja, extraterrestres que lhes passavam informações trazidas de uma cultura do mais alto nível.

\section{Os Sofistas}

Os sofistas são professores ambulantes com o propósito maior o de educar, surgindo o movimento após a vitória de Atenas sobre os persas, 479 a.C., e marca a consolidação da Democracia ateniense, no século V a.C. As características delimitam sua posição ante a Filosofia vigente, com uma forma diferente de ensinar e um motivo utilitário estabelecendo, assim, nova Pedagogia; mostra, também, a antiguidade desta área de Ensino na sociedade. Trata-se da formação de cidadãos aptos à vida pública, exigindo deles orientação correta à Oratória; enfim, a formação de alunos que saibam argumentar, em público, temas dos mais diversos, inclusive o da navegação celestial com o propósito da análise das constelações estelares, dando origem aos primeiros ensaios da Astrologia. É dessa educação que se encarregam os sofistas.

Sofista vem da palavra grega sofia, significado de ao tempo, homem de ciência ou professor e dizia Protágoras "só bem mais tarde adquiriu a significação pejorativa graças à luta renhida que lhes foi imposta”.

[A posição dos sofistas e de seus propósitos se justifica pela necessidade que o homem tinha de se educar e instruir à nova cidadania helênica, porque antes o cidadão perfeito era o lutador de arena, o esportista de corpo musculoso e bem desenvolvido; enfim, a força física preponderava antes de tudo].

Uma vez a Democracia estabelecida, em que todos os direitos eram assegurados aos cidadãos em geral, principalmente aos jovens educados, cultos e sapientes. Cidadãos capazes de desempenhar qualquer cargo na sociedade e, assim, o conhecimento se tornava imperiosamente indispensável, tornando o território grego local de sábios e dentre todas as cidades, Atenas se tornava uma supercidade. Mas quando se se refere aos professores ambulantes, tem-se o motivo em si de que eles se aventuravam por caminhos difíceis e incertos de vencer por quantos perigos se ofereciam; todavia, iam de cidade em cidade, ensinando aos jovens tudo aquilo que não soubessem e precisavam aprender no intuito de se tornarem aptos a concorrer aos diversos empregos públicos que estavam a 
surgir. Além do incentivo aos estudos, os sofistas ensinavam o valor do emprego na vida de uma sociedade.

Cumpre salientar que os sofistas preparavam os jovens para as lides democráticas, na Administração Pública, na Política, na Magistratura e nas ocupações que exigiam conhecimentos intelectuais e de fácil raciocínio. Por outro lado, também foram tachados de mercenários, porque como qualquer outro profissional do Ensino, cobravam seus préstimos e em premissa final inauguravam a Docência, por meio das primeiras pinceladas ao perfil de um verdadeiro Mestre e/ou Professor, acontecido pela primeira vez na Magna Grécia e com grande escândalo pela cobrança que exigiam dos alunos. Todavia, era o cerne do Magistério que, por sua vez, viria germinar com abundância.

Na verdade, o escândalo não atingiu o povo alheio às lides da intelectualidade mas, sim, aos filósofos que não-somente não aceitaram a medida inovadora como, também, criaram uma guerra sem trégua, a maioria aos sofistas. Premissa maior: enquanto os sofistas preparavam os moços para nova forma de Ser, na qualidade de cidadãos obreiros da sociedade, os filósofos continuaram seus esforços para explicar o Ser em sua natureza indeterminada e inacessível aos sentidos, mas com fundamentos metafísicos da realidade existencial infinita.

Dentre os filósofos, Sócrates e Platão foram os mais acirrados censores dos sofistas e de sua sofística, defendendo com denodo e habilidade a Filosofia em sua essência pura e irredutível. As ideias sofísticas abalam a Filosofia que, mais tarde, iria considerá-los seus inimigos, cujas críticas alcançaram um limite insustentável nas quais os sofistas nem sequer eram considerados filósofos. E assim, a palavra sofista passa a ser interpretada como demagogo e sofisma ganha o sentido de argumento falso, A inconsistência proclamada pela sofística torna-se assunto grave, a qual deveria ser atacada pela raiz definitivamente e assim fizeram sem rebuço.

Ser é precisamente consistir; portanto, as coisas consistem em algo e sem essa consistência não há coisas. E este Princípio tem sido preservado até nos dias de hoje, neste século XXI. O consistir é fundamento da Filosofia e é ele que mantém a existência da realidade metafísica, no pensamento perquiridor.

Mas pondera-se: é digno da menção a realidade e o de que os sofistas lançaram no mundo os fundamentos didáticos e pedagógicos da Docência profissional. Enfim, sensacionismo onde o relativismo e o conhecimento das verdades viriam mediante argumentos dialéticos que, posteriormente, foram denominados sofismas.

\section{Protágoras e Górgias}

Protágoras (485-410 a.C.) é Autor da exponencial frase, de que todos historiadores repetem ao se referirem ao problema do conhecimento: o homem é a medida 
de todas as coisas, do ser das que são, e do não-ser das que não são. Além da frase emblemática escreveu um livro herético intitulado Sobre os Deuses, no qual coloca em dúvida a existência dessas divindades, embora alegando de maneira sensata as suas razões. Quanto aos deuses, dizia: “não posso ter certeza de que existem, nem posso saber que aspecto devem ter, pois há muitos motivos que me impedem de ter um conhecimento seguro a esse respeito; e entre eles, a obscuridade do tema e a brevidade da vida humana."

Nessa época, a Filosofia se afasta das investigações dos pré-socráticos no âmbito da Natureza e o Universo para se ocupar das questões estritamente humanas. E Protágoras passa a ser considerado o primeiro sofista que significa, por sua vez, que o mundo é aquilo que o homem faz e desfaz, por intermédio dos sentidos. E caso haja um Princípio único ... o ser humano não pode conhecê-lo!

Protágoras se apoiava numa posição cético-relativista e passou a ser classificado pelos historiadores modernos como o Pai do Relativismo e precursor do Ceticismo e do Positivismo. E é por isso que é visto, também, como o Pai da Ilustração grega, marcando na História do Pensamento com antecedência de dois milênios o século europeu das luzes. Trata-se de um homem de extraordinário conhecimento. A sua Teoria do Conhecimento é extraída da seriedade científica de fato que partiu inicialmente da doutrina de Heráclito, o filósofo do eterno fluir das coisas e Protágoras procurava mostrar a impossibilidade do conhecimento verídico e estável, ao mesmo tempo que acentuava o caráter relativista do conhecimento. Daí a sua famosa frase vista acima.

Desta forma, o problema sartriano de Ser e do Nada está implícito, antecipando, assim, o Existencialismo, embora em sentido diverso, porque para Protágoras o Ser não é o "em si” estático de Jean-Paul Sartre, mas o "para si” dinâmico, relativista da ação em que o Ser, não sendo é ao mesmo tempo o Ser. E o que mais aproxima Protágoras de Sartre é exatamente esta posição antinômica e contraditória.

Para Protágoras, no pensamento, tudo é movimento, porque as coisas são produtos do movimento; todavia, este movimento se processa dentro de uma Lei dialética. É necessário o conflito de dois movimentos correlativos, inclusive de direção contrária: um chamado ativo e outro passivo, para que as coisas surjam. Em suas dúvidas da existência de uma verdade única, os sofistas acabaram irritando os cidadãos da Pólis. Segundo historiadores, Protágoras teria sido condenado. Ele mesmo já esperava por sua condenação, após a publicação de sua obra intitulada $A$ Verdade, na qual questiona em Sobre os Deuses a impossibilidade de se decidir sobre a existência dos seres divinos. ${ }^{6}$

\footnotetext{
6 Os gregos da Antiguidade tinham muitos deuses e deusas, assim como os romanos. Eram munidos de forma humana que controlavam aspectos da vida, porque para os helênicos eles se comportavam como os homens e as mulheres mortais; porém, dotados de conflitos. Venerava-se uma divindade específica quando se precisava de sua ajuda. Exemplo, uma gestante grega faria oferendas a Ártemis, a deusa do parto. Os gregos acreditavam que antes de seus deuses e deusas terem nascido houve uma raça de seres gigantescos
} 
Os demais sofistas conhecidos são Hípias, nascido na Élida (século V a.C.) e Górgias (487-380 a.C.). Com relação a Hípias se conhece a obra de sua autoria intitulada Diálogo Troiano, na qual aborda a área da Educação e a educação a ser seguida aos ensinamentos dos jovens.

Górgias nasceu em Leontino, Sicília e foi um dos mais eminentes oradores gregos. Nesta época, a Sicília, atual Sul da Itália, era habitada e comandada pelos gregos. Górgias escreveu um livro intitulado Do Não-Ser, no qual transparece clara dependência eleática, mostrando, também, as dificuldades de sua doutrina sobre o ente. Ele afirmava que o ente não existia; porém, se existisse não seria cognoscível pelo homem e se fosse cognoscível esse conhecimento não seria comunicável. Por fim, chega-se com os sofistas a uma última dissolução da dialética do ser e do não-ser de Parmênides, segundo ensinamentos de Julian Marias em História da Filosofia.

Premissa final: para Górgias o que existe é o Ser, na forma eleática de concepção do Ser. Não é de se admirar que Jean-Paul Sartre faz o mesmo em seu livro O Ser e o Nada, onde o Ser em si nega-se a si mesmo para aparecer na ação e entrar em relação com os outros. A interpretação da obra de Parmênides foi desenvolvida com dedicação por Górgias; nos anos finais da sua vida, dedica-se fielmente às linguagens greco-romanas.

\section{O Período de Ouro do Helenismo filosófico: Sócrates, Platão e Aristóteles}

Este Período abrange os séculos V e IV a.C. Época de Péricles. ${ }^{7}$ Nas cercanias, a bela Taormina até hoje abriga o anfiteatro grego, considerado dos mais antigos

chamados Titãs. E dois deles, Réia e Cronos, foram os pais de muitos outros deuses. Os seres humanos teriam sido criados por Prometeu; outros, também humanos, pelo deus supremo, Zeus. Réia e Cronos foram os pais dos deuses olímpicos. Cronos temeroso de ser destronado pelos filhos os engoliu, mas Réia escondeu nas montanhas o filho caçula Zeus. Tempos depois, Cronos regurgitou os demais filhos. E depois de uma batalha contra os Titãs, Zeus se tornou o principal dos deuses. Seu Reino especial era o Céu. Generoso, ele deu o mar e o mundo subterrâneo a Poseidon e a Hades, seus irmãos. Zeus usava os raios em sua defesa, castigando os seus inimigos e com eles também fazia justiça. Dada a sua beleza teve inúmeras esposas e amantes. Ele vivia junto aos outros doze deuses e deusas no topo do Monte Olimpo, a montanha mais alta da Grécia. E cada divindade representava pelo menos um aspecto da Vida: Afrodite era a deusa do amor, Hefaístos, deus do artesanato e Ares, deus da guerra. Por último, segundo a Mitologia grega, o primeiro ser do Universo foi Gaia, a deusa da Terra que surgiu do Caos primevo. Ela criou o mar e as montanhas e deu à luz Urano, deus do Céu. Gaia e Urano foram os pais dos Titãs.

7 ["Desfrutamos de uma Constituição que não é uma cópia da Jurisprudência de outros Estados; ao contrário, nós representamos um modelo para os demais Estados. E, com razão, nossa forma de Governo se denomina Governo do Povo, uma vez que o Poder não recai sobre os poucos, senão sobre a totalidade". Estas afirmações são atribuídas a Péricles, que regeu os destinos de Atenas no século V a.C. e podia com todo o direito de se sentir orgulhoso do sistema político da sua Pólis: um Governo nas mãos do povo, baseado em precisas Leis que estavam escritas e que era exercido por meio de eleições; em definitivo uma Democracia. Péricles atraiu para Atenas renomados arquitetos, artistas, biólogos e filósofos. O seu objetivo era o de dar à cidade ateniense um aspecto que fosse compatível com sua notável categoria política. Atenas deveria se 
do mundo, junto a Sócrates (470-399 a.C.), filho de Sofronisco, escultor e de Fenarete, exímia parteira, de família ateniense simples e regrada. O filho do casal, Sócrates, foi verdadeiro apostolado em favor do Bem e da Verdade que jamais se desmereceu; muito pelo contrário, por esses valores positivos se bateu denodadamente até o último instante de sua vida, por meio exemplar de extrema tolerância com os seus desafetos, cruéis e inescrupulosos. É que Sócrates foi condenado à morte ignominiosamente sem culpa justa em 399 a.C., única e exclusivamente pelo despeito e inveja que foram articulados ao seu redor, afetando o grande pensador em um processo que atualmente a História condena, uma vez comprovada a sua inocência e a malquerença de seus algozes.

Segundo os seus amigos que o respeitavam, Sócrates comparava a sua vida com a de sua mãe, porque, como ela, partureava a verdade. E com a mesma solicitude com que sua genitora atendia ao nascimento das crianças, assim também Sócrates atendia à valoração da verdade em sua pura realidade, onde quer que fosse e a todos os momentos. Todo o seu desempenho aos estudos foi à busca da realidade que se escondia, às vezes ambiguamente, nas próprias palavras ou na intenção que as envolvia. E com essa disposição de ânimo, conseguiu chegar ao conceito das coisas.

Todavia, Sócrates nada deixou escrito, mas seu aluno Platão erigiu em seu nome a vastíssima filosofia repleta das verdades que legou à Humanidade. E o próprio Platão é quem conta que Sócrates tinha o hábito de sair às ruas ou à praça pública no cumprimento de uma missão: a de provar a sua ignorância como, também, a de seus interlocutores.

Nesse comportamento, certa vez indagou a um general "o que era a coragem" ... a resposta não o satisfez; em outra ocasião, a um juiz perguntou "o que era a justiça”, obtendo a mesma desilusão. Enfim, a todos que passaram ao alcance de sua voz indagou resoluto e confiante na perspectiva de respostas alvissareiras.

converter no centro do mundo civilizado. Essa ampla estratégia pretendia conseguir o que ainda hoje se considera a essência da civilização helênica: a educação do cidadão em prol de sua maturidade cultural e política. Mediante série de adjudicações de impressionantes obras públicas, Péricles, político ambicioso, impulsionou a economia nacional, criou inúmeros postos de trabalho e deixou como legado uma herança valiosa ao mundo, um dos complexos arquitetônicos mais extraordinários da História da Humanidade. E por esse motivo se conhece o período de seu Governo, de 461 a.C. a 429 a.C., como a Era de Péricles inclusive considerado o período de maior esplendor da Grécia clássica. Além de Sócrates ter sido um marco na História da Filosofia, ele teve o privilégio de participar de uma vida cultural permeada por exímios artistas, enfatizando os dramaturgos e seus elencos além de escultores trazidos à Atenas por Péricles. Todavia todo este esplendor apresentou preço alto, uma vez a hegemonia de Atenas ter feito com que as rivalidades com Esparta culminasse com a Guerra do Peloponeso, em 431 a.C., quando Atenas capitula em definitivo. A derrota fez com que o regime democrático enfraquecesse, cedendo lugar ao Governo dos Trinta Tiranos. Mais tarde, restaurada a Democracia em 403 a.C., nunca mais seria a mesma época em que Sócrates - devido a crise de valores políticos e morais intensos dada a corrupção, intrigas e conspirações - fosse condenado]. 
O conceito se acha no modo pelo qual realizava a pergunta. Ele dizia: "Daime o 'lógos' da coragem, o 'lógos'da Justiça'.

[Lógus é uma palavra grega que foi versada para o latim na palavra 'verbum'. Lógos significa discurso, palavra dotada de sentido; de modo particular denomina-se 'lógus', o conteúdo que dá a razão de alguma coisa].

Desta forma, Sócrates queria saber o que os seus interlocutores entendiam por coragem, justiça, verdade verdadeira e outros temas. E assim, concitava os homens a fazer conhecimento real que os ajudasse a observar uma ética que emergisse da razão e da consciência. E ele estava certo de que o homem só errava por ignorância e o sábio possuía a fortuna de não-errar em razão do seu saber. A palavra passou, desde então, a ser conceito ou a significar unidade mental, englobando uma multidão de coisas ou de seres.

Assim como a datação da época do Cristianismo, Sócrates é um marco, uma vez aos que vieram antes dele receberem, embora haja diferenças, o nome genérico de "os pré-socráticos". Cumpre salientar, ainda, segundo historiadores que há quem considere que a Filosofia propriamente dita só iniciou... ou só chegou à maturidade por meio de Sócrates.

A dificuldade que os interlocutores tinham para responder as perguntas de Sócrates, provinha das indagações abstratas que o homem até então não estava acostumado a ouvir com a finalidade de sobre elas raciocinar. Pouquíssimas pessoas estavam preparadas para responder imediatamente sobre conceitos abstratos. Sócrates despertava as inteligências ao exercício de abstração, de reflexão filosófica... a seu modo!

Referindo-se a Sócrates, Aristóteles (384 a 322 a.C.) nos assevera categoricamente que a ele devemos duas coisas importantes: "os raciocínios indutivos e a definição universal" e que tanto um quanto o outro são ingredientes que se referem com valoração ao Princípio da Ciência. Por quê? Porque dar a razão de uma coisa é defini-la, é limitá-la, é determiná-la; enfim, é dizer o que essa coisa é em sua essência.

Aristófanes (445-386 a.C.) considerava Sócrates um sofista e não há razão para assim classificá-lo, porque enquanto os sofistas ensinavam a argumentação, isto é, argumentar com absoluta convicção sobre qualquer assunto, Sócrates, ao contrário, elimina as certezas, por meio de melhores argumentos. Dentre as imagens de seu legado, a frase imortalizada: "só sei que nada sei”. A Sócrates interessam o homem junto às suas ações, aquelas tidas como virtuosas em uma época que ser virtuoso é quase sinônimo de cidadão e tudo se justifica em nome da virtude, incluso as injustiças. Sócrates sempre pergunta; dentre todas: o que é a sabedoria, a beleza, a coragem, a justiça, porque procura, a partir desses diversos aspectos chegar à seguinte questão: o que é a virtude? Uma vez conhecê-la, torna-se o principal objeto do verdadeiro conhecimento: só pratica o mal quem ignora o que seja a virtude. E quem tem o verdadeiro conhecimento só pode agir bem. E assim, conhecimento e virtude tornam-se sinônimos. Por meio de Sócrates, as 
questões morais deixam de ser tratadas como convenções baseadas nos usos e costumes, as quais modificam conforme as circunstâncias e os interesses, para se tornar problemas que exigem do pensamento uma elucidação racional.

Premissa final: nesse sentido, Sócrates é o fundador da Ética! Além da Ética, o Direito Natural no mundo antigo vem de Sócrates, porque ele era radicalmente impedido pela convicção de que a Divindade lhe confiara a missão de ensinar os homens a serem melhores pela prática das virtudes. $\mathrm{O}$ melhor homem é o justo, aquele que não causa mal a ninguém.

Mas como se ensina o homem a ser justo, para consigo mesmo e para com os outros? É simples assim: ensinando-lhe o que é a verdade e o bem, pois quem conhece uma e outra coisa, torna-se só por isso, bom; todavia, como se pode conhecer com certeza a verdade e o bem? Mediante análise ou exame das coisas que permitem descobrir a essência ou definição de cada coisa, conhecimento válido perante todos. Assim se descobre e se prova o que é o justo, o belo, o útil, o bom, o verdadeiro e outros.

E esta técnica de conhecimento fornece a verdade, e é superior ao saber dos sofistas que, por sua vez, se contentavam com verossimilhança, a aparência, o relativo e permite constituir uma Ciência, válida para todos. E que fundamenta na certeza a conduta que os homens devem ter, nesta vida. O justo é o que realiza o melhor da Natureza humana em si e para os outros, praticando o bem e evitando o mal. $\mathrm{O}$ conhecimento verdadeiro revela em que consiste a conduta justa, examinando as diversas condutas e os seus efeitos, na vida. E o Direito faz respeitar a conduta justa, na sociedade.

Nas últimas palavras de sua defesa no Tribunal ateniense, Sócrates põe a claro o efeito supremo que a Justiça tem: esta é algo inobscurecível nesta vida, e absolutamente respeitada e satisfeita no que virá depois do Tempo: "Não há mal possível contra o homem de bem, nem nesta vida, nem depois da morte, e os deuses não são indiferentes à sua sorte".

Dos quinhentos juízes do Tribunal dos Heliastas, 280 condenaram Sócrates e 220 o absolveram: a perda foi de sessenta juízes, a maioria julgadores invejosos, arrogantes e inescrupulosos, principalmente após o pronunciamento da Pitonisa de Delfos ${ }^{8}$ sobre a sabedoria de Sócrates.

8 Delfos se situa aproximadamente a duas horas, de carro, de Atenas; não é somente uma joia arqueológica. Devido à sua privilegiada localização, na encosta de uma montanha sobre o mar, constituiu-se um dos conjuntos antigos mais belos da Grécia. Lembro que Atenas e suas ilhas ao redor foram desenhadas por vulcões que erigiram um lugar dos maiores e mais belos aos olhos da Humanidade. A importância de Delfos desfrutada em outros tempos era o de um centro cultural do mundo helênico e se baseava em três fatores principais, a saber: a cidade abrigava o Santuário de Apolo mais importante da Grécia. Era como Olímpia, uma das sedes dos populares Jogos Pan-helênicos, além de possuir um oráculo conhecido em todo o mundo antigo. Segundo historiadores gregos, certa ocasião Zeus quis encontrar o centro do mundo. Ele enviou duas águias desde os dois extremos do Cosmos e o ponto onde os dois pássaros de rapina se encontraram foi a 
Certa vez, Xerefon, filósofo, teria consultado o oráculo de Delfos para saber qual seria o homem mais culto, em sua época, de toda a Magna Grécia. E a resposta obtida pela Sacerdotisa de Apolo teria sido ["Sábio é Sófocles, mais sábio é Eurípedes, mas entre todos os homens, Sócrates é sapientíssimo!’]

Após a votação dos heliastas, Sócrates realizou vários discursos, enfatizando àqueles que o absolveram e enquanto alguns procuravam se reunir para saber o lugar onde ele seria morto, debaixo de profundo sentimento de consternação pairado sobre aquelas almas bem-informadas que souberam compreender o altivo e sereno filósofo, a eles o velho sábio fez o último:

- Das duas, uma: ou a morte é o inteiro esquecimento, ou é a passagem da alma de um para outro lugar. Se tudo se destrói, a morte é uma noite sem sonhos e sem consciência de nós mesmos; noite eterna e feliz! Se ela é somente a mudança de lugar, que felicidade poder reencontrar aqueles que conhecemos e poder privar com os sábios. Mas é tempo de nos despedirmos; eu para morrer, vós para viverdes! A qual de nós está reservada a melhor sorte? É um segredo para todos, exceto para Deus.

\section{Platão, o porta-voz de Sócrates}

Platão é o discípulo dileto e fiel intérprete da obra de seu mestre como continuador entusiasta de sua filosofia - a que não poupou detalhes -, pondo em evidência a riquíssima substancialidade de seus conteúdos. Nascido na Ilha de Égira em 429 a.C., viveu até 347 a.C. Historiadores/pesquisadores tomam esse cálculo na referência de nascimento e morte calcados na invasão da Grécia por Felipe da Macedônia, acontecimento histórico que marca, também, a decadência artística e política da Grécia.

O problema de Platão é o mesmo que vinha sendo colocado por todos os présocráticos, desde Parmênides, ou seja, o do Ser e o do Não-Ser que, por sua vez, procurou

região de Delfos. Desde então, os gregos antigos batizaram o lugar como "Umbigo do Mundo". A lenda grega também conta que as belas águias se fixaram sobre dois picos rochosos, as Fedríadas ou "Luminosas", em cuja base nasce a Fonte Castália. E precisamente neste local foi erguido o Santuário à Gaia, a deusa da Terra, vigiado de forma eficaz por uma serpente chamada Píton. Apolo, filho de Zeus, a matou, assegurandolhe o domínio daquela área. E desde então, o deus da luz foi adorado naquele lugar como Apolo Pítio. Em visita ao local, 1999, verifico que a estrada atual, correspondente pelo menos àqueles anos, divide o conjunto arqueológico de Delfos em duas partes: na parte inferior se encontra um sítio secundário que abriga as ruínas de um pequeno templo circular dedicado à deusa Athenea Pronaia, o Tholos, uma das mais belas construções da Grécia antiga. Na parte superior se encontra amplamente distribuído pela montanha, o distrito sagrado propriamente dito. Na sua época de esplendor - entre os séculos VIII e IV a.C. -, oferecia impressionante vista panorâmica aos peregrinos que a ele acudiam procedentes de todas as partes do mundo ... e atravessavam a "avenida sagrada". O que devia ter sido emocionante para eles! 
minimizar o quanto possível. Era o enigma vigente que proclamava, imperiosamente, o pensamento na busca de alguma solução, porque todas as tentativas se mostravam inócuas, até então, não-obstante o pensamento estava se adequando, gradativa e vagarosamente, a uma forma de reflexão propícia, desbravando a rudez da aspereza natural à incipiência e trazendo um pouco de luz que culminaria na abertura colocada por Platão, no tabernáculo do Ser.

Nesse ínterim em que Platão tinha consciência da magnitude do problema, ele se amparava no vigor espiritual de sua ascendência pedagógica que consubstanciava no desprendimento individual e o amor ao próximo que, na verdade, eram dignidades pessoais de seu amigo e mestre, Sócrates. E assim, dando continuidade aos seus estudos, adquire uma propriedade nos arredores de Atenas e funda a Academos, em 387 a.C., tornando-se ali uma Escola: a Academia, espécie de irmandade com conotações filosóficas e religiosas, onde se discutia livremente temas como Astronomia, Matemática, Música, Dramaturgia, cujo portal da entrada, a inspiração pitagórica, onde inclusive se lia 'Não Entra Quem Não Saiba Geometria'. E nela fixou-se a se empreender em seus estudos sobre Ideia e Ser, demonstrada em sua obra Teoria da Ideia (Eidos). "Eidos" é uma palavra grega que significa ideia, figura, aspecto, aquilo que se vê. Ideia é pois o que vemos quando olhamos as coisas. As ideias são o extrato de tudo o que conhecemos, a síntese do conhecimento proporcional às nossas vivências. As ideias, segundo Platão, são a representação que ficou em nossa memória, de nossa experiência externa, o arquivo que constitui a consciência, conhecimento e, nesse caso, a consciência é um complexo metafísico que comporta multidões.

As ideias são unas, imutáveis, eternas, isto é, puramente são, sem restrições. Por outro lado, as coisas são exemplares imperfeitos das ideias, isto é, as ideias são perfeitas, absolutas e eternas; as coisas são transitórias, diversas, imperfeitamente semelhantes às ideias. Finalizando, para Platão, a alma (Espírito) convive com as ideias antes de nascer e lhe fixa a reminiscência daquela convivência e por certo esforço pode, encarnado, extrair dessa longínqua lembrança (ideias inatas) o conhecimento e até mesmo pela associação das ideias vigentes, a das formas sensíveis das coisas, tirar de umas o conhecimento de outras. E certo estímulo se processa nos refolhos de sua memória profunda; e o conhecimento emerge lá do fundo o id, do inconsciente.

Para Platão, o homem é um ente caído (Teoria dos Anos Insubmissos), mas surge novamente caracterizado como tendo vislumbrado as ideias, ou seja, o verdadeiro Ser das coisas. E, assim, ter participado da verdade e isso representa uma marca definidora, um argumento propício à ideia de imortalidade. 


\section{O Mito da Caverna de Platão}

Cumpre salientar, preliminarmente, que o mito de Platão não se trata de um conto fictício ou fábula mas, como encenação real, alegórica e dramática da História da Humanidade em sua ascensão espiritual ao sair da ignorância para penetrar o plano da consciência, se realizando gradativamente como ator, em pleno exercício, no palco da existência ou no picadeiro da Vida. Trata-se de uma fórmula didático-pedagógica, cujo intermédio, o conhecimento, é transferido ao vivo em uma associação teóricoexperimental dos tempos modernos ao recesso do laboratório.

E Platão cria o seu mito:

Em uma caverna escura onde moram, desde crianças, um mundo de pessoas. Elas não podem olhar para cima; somente para a parede em frente ou para baixo. Lá em cima um povo civilizado se movimenta: vai e vem passando ao lado da caverna, de tal modo que o Sol claro projeta na parede da caverna as suas sombras. Por vezes conversam e suas vozes chegam aos ouvidos de alguns, não de todos. A realidade existencial é para eles apenas sombras que alguns até dizem ouvir! Outros nem acreditam, pois tudo é somente sombra. Certo dia, um daqueles moradores mais afoitos e habilidosos escala a parede. Sobe e entra em contato com a realidade verdadeira; são pessoas que se movimentam, falam, agem, fazem coisas extraordinárias. Foi muito difícil nos primeiros momentos se adaptar; a luz era demasiadamente forte, de tal maneira que não permitia abrir os olhos à vontade. Mas acabou conseguindo; finalmente, pôde e então era preciso contar aos companheiros algo de toda aquela beleza. Voltou e fez o quanto lhe foi possível. Mas muito poucos o acreditaram, passando por mentiroso e por bruxo. Ele foi perseguido e finalmente condenado à morte.

Essa homenagem de Platão a Sócrates sintetiza nele o símbolo da caverna, cuja vida cedeu em holocausto essa verdade que a Filosofia ou os filósofos procuram para acender como luz, fé e sabedoria em seu próprio favor e em favor da felicidade humana.

\section{A Teoria da Alma e a Ética}

A origem mítica do homem é dada em Fedro como tendo sido a queda de uma alma do Topos Uranos e que uma vez alojada em um corpo humano, teve de se adaptar às Leis físicas, ao nascer, ao morrer, à dor, ao esquecimento. E como esteve em contato direto com as realidades existenciais, consequentemente com a verdade e o saber, por um pequeno esforço pôde extrair de si mesmo algumas verdades e algum 
conhecimento. A imortalidade tem seu fundamento nesse mito, o da reminiscência, que as religiões propalam e que Platão ressaltou em sua filosofia.

A tradição platônica atribui à alma três partes:

* a primeira concupiscente ou sensual que está intimamente relacionada com as necessidades corporais,

** a segunda parte corresponde aos impulsos e afetos naturais que estimulam o ser corporal por meio dos reflexos psicológicos;

*** a terceira é a racional que possibilita o conhecimento, a estruturação da consciência, o sentido da liberdade e consequente responsabilidade e preponderante volição.

O amor é para Platão um estado de privação, na busca de algo que não se tem; aquilo que falta. O amor é mitologicamente filho de Poro e Penia. É também a riqueza, mas, ao mesmo tempo, indigência. E esta indigência é a força que impele o Ser à busca do amor que falta. Finalmente para Platão, a beleza (que vem do que é Belo = Verdadeiro) é mais facilmente visível que a verdade. Arrematando, a ética platônica é intelectualista e está dividida em quatro funções fundamentais que devem ser instruídas pela Razão mais que pelo sentimento:

a sexualidade requer moderação; uso disciplinado sem conflitar com o impulso natural. As afetividades fazendo-as coincidir com o bom ânimo, sem pender para a afetação e, sim, para a fraternidade no âmbito universal. A Razão querse prudente, tocada da sabedoria, serenidade e Justiça. E a quarta dimensão dessa tetralogia é a Justiça que deve ser exercida com amor e fraternidade, segundo Platão!

\section{Aristóteles}

Aristóteles nasceu em Estagira em 384 a.C. Seu pai era médico, Nicômaco, e atendia a Corte do Rei Filipe, da Macedônia; este, pai de Alexandre Magno, cuja relação com Aristóteles foram motivos em 323 a.C., de suspeitas, levando-o ao Tribunal de Atenas, sob pretextos religiosos, após a morte de Alexandre III, que tinha sido preceptor do filósofo em 343 a 340 a.C., desde os treze anos de idade.

Aristóteles tinha o pseudônimo "O Estagirita", por ter nascido em Estagira, na Região da Península Calcídica e cidade dependente da Macedônia, cujo Reino mais tarde seria um grande Império, subjugado à Grécia e depois à Pérsia; porém, não se limita ao local de seu nascimento. O mais importante, com relação ao seu perfil, é a de que Aristóteles é um homem de gênio, uma vez levar a Filosofia grega à sua máxima expressão de conhecimento, alcançando-a à possível plenitude. Sem prever, faz coincidir a 
superlativa culminância com a linha declinatória com que se inicia a sua decadência. E é o último dos mais eminentes filhos da Grécia antiga que construiu o acervo do conhecimento filosófico que a História da Filosofia assinala no conceito de Realismo Metafísico.

Cumpre salientar novamente que depois de Aristóteles ninguém mais aparece e o pensamento grego se trivializa no engenho meticuloso de um novo estado de coisas, uma vez que a Grécia havia terminado a jornada de sua missão no âmbito do Universo e do conhecimento filosófico. De tal maneira, que nas terras gregas não nascem mais filósofos e, sim, os mestres que têm na carreira destinada o propósito de difundir os conhecimentos suficientes e inerentes às possibilidades e às necessidades nacionais. Todo o povo de uma Nação tem a tarefa determinante a desempenhar neste planeta, cujo propósito é o de vestir o curso da História da Humanidade e da História da Filosofia.

Premissa final: Platão e Aristóteles são a chave-mestra do escrínio da sabedoria antiga universal. Aristóteles escreveu livros exotéricos, destinados ao grande público em forma de diálogos (diá = através, por meio de $)$; $(\operatorname{logos}=$ discurso $)$ e outros esotéricos sobre questões mais profundas e todos eles destinados aos alunos do Liceu. Todos os diálogos se perderam, restando apenas alguns fragmentos; todavia, a parte fundamental científica foi preservada. Ele classificou as ciências como a. Teóricas; b. Práticas e c. Poéticas.

Poesis de que deriva poesia, significa produção, fabricação; refere-se a uma atividade que tem em si o interesse.

Práxis, significa uma atividade por ideal, por simples ocupação e Theoria ou teorética que significa contemplação é uma espécie de práxis. A contemplação é uma atividade que tem em si mesma a sua finalidade; pode ser, por exemplo, estudar Filosofia, Arte, Desenho, Teatro e outros.

Para Aristóteles, a palavra Ser não é equívoca, embora seus múltiplos sentidos, porque estes possuem nexo entre si, isto é, têm significação semelhantes. É uma palavra análoga ou analógica. Ao se referir ao Ser, Aristóteles concluiu que quanto ao Ser, este se pode dizer de quatro modos:

* O Ser por essência ou por acidente;

* O Ser segundo as categorias da Razão;

* O Ser em potência e o Ser em ato.

Em suas obras, aborda o conceito de substância, a qual não é um atributo, nem predicado. É um sujeito, aquilo que existe em si, independentemente de qualquer coisa. Substância é uma palavra traduzida de ousia que se emprega também em outros sentidos. É sub-stantia: aquilo que está debaixo, suporte, sujeito no sentido de sub-jectum que significa abstrato. 
Os gregos empregavam também a palavra hipojeimenos: jazer por baixo, ser eternamente o mantenedor. E para explicar a estrutura ontológica da substância, Aristóteles cria a Teoria da Forma e da Matéria, tomando como preâmbulo a substância composta de dois elementos: forma e matéria. Tudo o que existe se mostra, fisicamente, por meio de uma forma do Ser. Matéria é aquilo ou algo de que uma coisa é feita na acepção mais extensa possível, física e abstrata.

O saber para os pré-socráticos era discernir tanto para Sócrates quanto para Platão no intuito de definir, aplicando os conceitos. Mas em Aristóteles é Ciência demonstrativa que faz, por sua vez, conhecer as coisas por suas causas e princípios.

As causas são as razões que levaram à realização das coisas e respectivos detalhes, E é por isso que estão assim classificadas:

* causa material;

* causa formal;

* causa eficiente; e

* causa final.

A causa material é referente à matéria de que uma coisa foi feita. A formal é a forma que se tem como, também, o que dá a forma. A eficiente é a mudança, o primeiro princípio do movimento que, por sua vez, causou a coisa ou, ainda, quem a faz. E a final, é o fim para o qual foi feito ou destinado, a sua finalidade.

Os princípios são a um só tempo, do Ser e do Conhecer. A Teoria do Conhecimento em Aristóteles como em toda a Filosofia está essencialmente vinculada à metafísica, uma vez que a Filosofia busca precisamente o conhecimento das coisas em seus fundamentos metafísicos.

A Ética de Aristóteles está contida nos dez volumes de sua obra Ética a Nicômaco, conhecida como uma das mais importantes no gênero. E no seu conteúdo compreende a exposição detalhada de série de conceitos, de sua autoria, sobre a Moral, constituindo a mais alta expressão da Filosofia-Ética grega.

A divulgação de sua obra veio por meio de seu filho Nicômaco (mesmo nome do avô) que, por sua vez, a conservou por meio dos tempos, cuja ideia conservadora fez com que se protegesse o nome do Editor e é por isso que a obra também é conhecida como Ética Nicomaquéia. Dentre a preciosidade da obra, os conceitos da conduta humana, por meio da Virtude, da Arte e da Moral. Aborda a Felicidade (momento da plenitude espiritual); A Vida Teorética (o mesmo que a vida contemporânea); as Virtudes (divididas em duas classes: virtudes intelectuais (dianoéticas) do pensamento e virtudes éticas mais propriamente morais. A obra conclui a Essência da Alma (o princípio da vida é a alma). Por último, a Natureza: Aristóteles discrimina a Natureza como princípio do movimento e do repouso em flagrante oposição ao eleatismo. Os seres vivos são naturais, porque têm 
em si o princípio do seu movimento, a saber: o germinar, crescer, alimentar-se, regenerarse e reproduzir-se. Esse procedimento constitui o que se chama movimento substancial. Deste movimento, se constitui o Direito Natural, ou seja, aquele conjunto de prescrições emanadas da Natureza do homem que deve ser seguido, a fim de se atingir a sua finalidade na existência que, por sua vez, é a realização de suas potencialidades.

Ao Direito Natural, Aristóteles chamava de Justo Natural. O Direito é um conjunto de regras de conduta que os homens devem obedecer em sua vida social, a fim de que possa ser, nela, respeitada a sua Natureza. Assim, a finalidade do Direito é o de assegurar que, na vida social, cada homem possa encontrar aquelas condições para realizar o seu Ser. Por isso, o Direito procura dar a cada um o seu; ora, dar a cada um o seu é a definição de Justiça. O Direito tem por objetivo a Justiça, de maneira que haja igualdade entre todos. Todavia, a igualdade da Justiça é uma igualdade proporcional e nela, igualdade proporcional, o Direito procura realizá-la de duas formas: realizando a Justiça Comutativa e a Justiça Distributiva. A primeira, visa a obter que nas relações de troca haja igualdade nas proporções dos bens negociados: coisa e preço, trabalho e salário. Pela segunda, visa obter que a repartição dos bens e dos encargos do Estado sejam feitas em proporção às necessidades e aos méritos de cada um. Logo, tanto em um quanto em outro fica partilhado a cada um o seu. (Aristóteles, Ética a Nicômaco, p. 112-115). Enfim, uma orientação jurídico-aristotélica à elaboração voltada ao perfeccionismo do nascimento do Direito. Jamais devemos esquecer daqueles que nos precederam e a nos ensinar a plena Democracia: os gregos.

\section{A Helenização do Cristianismo. O surgimento do Direito. A Ortodoxia. \\ 1. A Helenização do Cristianismo.}

Os gregos assim como os romanos da Antiguidade possuíam série de deuses e deusas com forma humana que controlavam diferentes aspectos da vida. Principalmente os gregos, que consideravam os deuses se comportando como homens e mulheres mortais; todavia, dotados de características distintas, com seus amores e conflitos.

Os gregos acreditavam, também, que antes de seus deuses e deusas terem nascido houve uma raça de seres gigantes intitulados Titãs e dois deles, Réia e Cronos, foram os pais de muitos outros deuses, o que na verdade eles estavam corretos haja vista a raça de gigantes de 12 mil anos a.C. terem habitado a Ilha de Malta, ao Sul da Itália. Asseveravam, por último, que a raça humana teria sido criada por Prometeu ou pelo deus supremo, Zeus.

Retornando, na verdade essa crença ou lenda tem veracidade para muitos cientistas, historiadores e jornalistas investigativos, baseados na História da Humanidade de que a Terra foi visitada por deuses das estrelas e que tendo manipulado o $D N A$ dos 
homens teriam procriado novas gerações de seres humanos, neste planeta. E o primeiro Ser do Universo teria sido Gaia, a deusa da Terra que surgiu do caos primevo. Gaia criou o mar e as montanhas e deu à luz Urano, deus do Céu. Ela e Urano foram os pais dos Titãs. [Conforme visto no rodapé de n. 7.]

As terras gregas foram ocupadas entre 2000 e 1450 a.C. pelos minoicos que criaram uma grande civilização na Ilha de Creta; logo em seguida, os micênicos do Continente europeu invadiram Creta e lhes impuseram seus usos e costumes junto à Religião. A esses povos, o culto à divindade era importante, sendo que a Religião minoica englobava símbolos como machados duplos, serpentes e touros, provavelmente símbolos de fertilidade. Os etruscos - que governavam o Norte da Itália antes dos romanos -, se aproximaram dos gregos e por eles foram influenciados na Religião primeva. Os deuses etruscos eram semelhantes às divindades gregas: Tin (etrusco) era como Zeus e Turan (etrusca) comparada a Minerva ou Atenas. Mais tarde, os romanos tomaram emprestados dos antigos gregos a maioria dos seus deuses e deusas; todavia, lhes deram nomes diferentes. Exemplo: a deusa grega do amor, Afrodite, passou a ser Vênus; Ares virou Marte e Zeus passou a ser Júpiter. Os gregos acreditavam que se o poder de uma divindade fosse reconhecido, ela lhes traria benefícios e para demonstrar a devoção, ofereciam sacrifícios diante dos templos e faziam libações em louvor a essa divindade. Outra forma de culto eram os festivais religiosos. Em geral, um festival na antiga Religião grega tinha uma procissão solene seguida de grande sacrifício. Também incluía competições como a I Olimpíada em homenagem a Zeus e disputas entre poetas, coros e atores dramáticos para celebrar outros deuses.

Nos períodos minoico e micênico, 2000 a.C., Hamurabi, Rei da Babilônia, estabelece o culto a Marduk conhecido também - em consonância à Bíblia hebraica -, como Baal que se torna reverenciado como o mais importante de todos os deuses pagãos. Se não houvesse credulidade ao deus pagão, o cidadão era punido por heresia; em síntese, a adoração ao deus Baal era imposta no Reinado tanto pelo Rei quanto pela sacerdotisa em toda a Região de caanenses e/ou territórios dominados pelos romanos, incluso a Região grega. Período do Código de Hamurabi, mais conhecido como a Lei das XII Tábuas, que se tornara exemplo aos demais Reinos daquela Era.

Todavia, a sociedade grega em parâmetro às outras civilizações de seu tempo desconhecia as castas sacerdotais que tivessem o monopólio dos Livros Sagrados e da verdade revelada como, também, a escrita é segredo de governantes e escribas, incluso o livre desenvolvimento do pensamento, o qual é facilitado pela ausência tanto na Religião olímpica quanto nas crenças mais místicas de uma Teologia elaborada que forneça explicações coerentes do mundo. Cumpre salientar que os deuses gregos têm características humanas e pouco servem para um pensamento mais elaborado, ou seja, 
de uma perspectiva política; a Grécia se apresentava munida de uma Religião frágil e ineficiente como instrumento de poder.

Reprisando, no período de Homero, a ideia de Rei divino desaparece, dando espaço para que a Política e o Governo se tornassem assunto de atividade essencialmente humano. Lembra-se de que a Grécia não é Império com domínio aos moldes do Império romano; pelo contrário, cada comunidade grega é uma cidade-Estado autônoma de dimensões a pequenos municípios. E esses pequenos municípios (pólis) tinham suas organizações independentes e próprias; mas, oficialmente, todas seguiam as diretrizes do modelo ateniense. E é em Atenas que o zoón politikón de Aristóteles surge em plenitude, orgulho dos atenienses, cuja característica se diferencia dos demais povos dos séculos VIII e V a.C. Nessa época, o homem é definido por Aristóteles como zoón politikón = animal político. A ideia de que a soberania é da Lei e não dos deuses ou Rei e constitui o fundamento da Democracia grega; até Esparta, mediante tantos aspectos diferentes, vem a imitar a Magna Grécia. Os destinos da pólis são de responsabilidade única e exclusiva de todo cidadão que tenha cidadania, acima de todos eles não há nada a não ser a Lei, elaborada por eles mesmos.

Nessas circunstâncias, o desenvolvimento da Filosofia: um modo de se pensar, no qual haja a busca de uma Lei Universal acima de todas as coisas, a qual explique o mundo das coisas sem se recorrer às forças divinas e místicas. Os romanos assim como os gregos formavam a sua pólis, por meio de vários povos, quando Roma foi invadida pelos latinos, sabinos, équos, por volta dos séculos IX a VIII a.C., os quais passaram a habitar a Região do Lácio, Península itálica. Eles formaram uma Federação e dada a organização fortificaram o território que lhes era comum, dando origem ao núcleo oficial de Roma, por volta de 753 a.C., cujo nome da cidade deriva de Rumon = cidade do rio, termo empregado pelos etruscos que a dominaram em 616 e 509 a.C.

Período de Alexandre - considerado um dos homens mais belos e cruéis da Antiguidade - imperador da Macedônia. O ímpeto guerreiro de Alexandre, o Senhor da Guerra, era descomunal, lutava pela Grécia. Com suas conquistas, torna-se imperador da Pérsia e faraó no Egito, títulos conquistados. Todavia, desprezados, uma vez querer conquistar a Índia, atacando a cidade de Taxila, primeira tribo indiana a sentir a força do Exército alexandrino. Na época, o território indiano era composto por dezesseis tribos, a maioria delas, sob o Reinado do Rei Pórus. Alexandre o desafia e atravessa as margens do Rio Hydaspes, em combate com o Rei e seu filho, que tinha o mesmo nome de seu pai, em confronto conhecido como a Batalha de Hydaspes e, pela primeira vez, seu Exército conhece nova estratégia - em parâmetro às guerras anteriores: -, os elefantes. Ele morreu em 323 a.C., aos 33 anos de idade; e menos de um século depois, a Macedônia - que se desagrega junto à Grécia, em dezenas de sub-impérios -, se encontra sob o domínio de uma nova potência: a cidade eterna, Roma. Mas os fatos jamais deixaram de pôr a 
Grécia no patamar, dada a perda de autonomia, pelas conquistas de Alexandre, em cidades gregas de cultura clássica, ultrapassando fronteiras de seu tempo. Os gregos construíram uma cultura, chamada mais tarde de helênica, das mais tradicionais e de sofisticado conhecimento tanto político quanto filosófico, com valores que passaram a adotar o idioma, a arte e o pensamento grego, influenciando os demais impérios, inclusive a própria Roma. Somente no plano político, a forma de Governo evoluído para o despotismo aos moldes persa e egípcio.

$\mathrm{Na}$ Religião, os deuses do Olimpo se tornaram gradativamente desacreditados. E nota-se ou se relembra que as adaptações gregas diziam respeito, inclusive, aos compreendidos entre si mesmos; mesmo porque, quando se expressava a palavra homem, seu significado básico era o de homem grego: um cidadão livre e da pólis; os demais eram classificados de bárbaros, significado de cidadãos desprezíveis e inferiores. Todavia, a medida que a pólis sucumbia ao Império romano, o orgulho do homem grego perdeu o fundamento. E assim, sem direção, gregos e bárbaros se igualavam na condição de súditos e o status de cidadão deixa de ser privilégio dos gregos: todos passam a ser considerados homens, membros de uma única Humanidade, participantes não mais de uma pólis, mas da cosmópolis; traduzindo, a eterna Roma. Porém estender a noção de Humanidade a todos os homens sem distinção significa, também, torná-la vazia e abstrata. Por quê? Porque antes na pólis ser homem indicava situação e condição precisas. Ou seja, participação na vida pública, além de decisão dos destinos da cidade-grega. Sob o Império, homens livres e escravos se equivalem, dando margem à não-participação e influência alguma na vida política; assunto alheio à maioria dos cidadãos e privilégio de algumas poucas pessoas que, por sua vez, têm o Poder substituído na comunidade. Premissa final: o homem não é mais um animal político em sua essência.

No plano do pensamento, época clássica, a Filosofia grega tinha como propósito, implícito ou-não, a definição do homem como animal político e fazia da Política a conclusão máxima da Moral e da Conduta Ética. Platão se afastou da Política justamente para fundamentá-la, isto é, a verdadeira Filosofia e Aristóteles afirmava que isso só era possível no âmbito da pólis, ou seja, fora da pólis o homem nada significava! Nessa época, três correntes filosóficas reinavam na sociedade: o Ceticismo, o Epicurismo e o Estoicismo.

O Ceticismo foi formulado por Pirro de Élida (360-270 a.C.), oficial de Alexandre, que nada escreveu e cujo pensamento é exposto por Tímon (320-235 a.C.) e mais tarde por Sexto Empírico, nos séculos II e III d.C., em Hipotiposes Purônicas. Ceticismo, do grego, significa olhar cuidadoso, olhar minuciosamente. Interessante é que o olhar cuidadoso equivale a duvidar do conhecimento. Enfim, o cético é, portanto, incoerente. O Epicurismo foi fundamentado por Epicuro (341-270 a.C,) que reunia seus discípulos numa Escola intitulada Jardim. A pauta maior para ele e seus alunos é a do 
estudo do Prazer, mesclado ao teorema "como a um prazer momentâneo se pode seguir desprazer ou dor, convém, então, procurar um tipo de satisfação estável, comandado e constante; algo como a sensação que experimenta com homem que não sente sede e, por isso, não bebe".

Premissa final: Epicuro considerava o Prazer uma realidade física, justamente porque para ele, na verdade, não existia nada além das coisas físicas e corpóreas, os átomos, e sua ausência, o vazio. Ele era seguidor da Teoria Atomista, de Demócrito. Finalmente, o Estoicismo que se divide em três períodos: primitiva (século III a.C.), do fundador Zenão de Cício e seus inúmeros alunos e a média (séculos II e I a.C.), quando se introduz em Roma com Panécio de Rodes e Posidônio de Apoméia; e a romana (séculos I e II d.C.) em que o Estoicismo se torna parte integrante da cultura e do pensamento romano, influenciando o senador Sêneca e o imperador Marco Aurélio. É a corrente filosófica grega que melhor traduz o espírito cosmopolita, cujo conceito é o de que

a felicidade consiste em viver de acordo com a ordem universal das coisas, permanecendo indiferente aos males, os quais não passam de aspectos isolados do todo racional. Viver de acordo com a razão significa se desviar das paixões, que são as perturbações da razão e se o Mundo é regido por uma Providência racional, então o importante é que cada um se reconheça como parte dela, acertando impassivelmente, sem paixão, a sua condição.

A História da República romana que neste artigo não cabe dissertar veio de várias conquistas, daí o propósito de fortificações acima assinalados, uma vez a Roma Eterna em sua defesa sempre ameaçada por povos vizinhos intitulados "os bárbaros". O resultado, o grande Império romano que nos séculos I e II a.C. abrangeria quase toda a Europa, incluso a Grécia por ela dominada, o Norte da África e a Ásia Menor. Em concomitância o pensamento romano floresce, mas ao contrário do que ocorreu na Grécia, a atividade intelectual romana careceu de originalidade. Na Filosofia, os cidadãos romanos elaboraram um pensamento eclético numa mistura de vários aspectos das correntes filosóficas gregas existentes, das quais sobressaem as ideias moralizantes e, além disso, esse pensamento não alcança nível de abstração comparável ao dos gregos, a não ser em único terreno: o do Direito. E no final do período do Império surgem fatos culturais novos: o Cristianismo e o Neoplatonismo.

Os gregos foram os pioneiros na abordagem filosófica científica ao mundo, especialmente durante os Anos Dourados de Atenas no século IV a.C., lembrando que era o tempo de Sócrates, seu discípulo Platão e seu discípulo Aristóteles, nesta sequência. Época da fundação da Escola próxima a Atenas, fundada por Platão que lhe deu o nome de Academia que era uma corporação aristocrática do mais alto nível. Nela, os platônicos desenvolveram um sistema filosófico baseado em seus pensamentos; um sistema que 
girava em torno da distinção entre o Mundo Físico e o Mundo Espiritual. Eles levavam as pessoas a olhar além do que seus sentidos percebiam ou proporcionassem como, também, a usar suas mentes em lugar da visão e, com isto, conhecerem a realidade espiritual. Os platônicos acreditavam que o Mundo Físico era apenas pálido reflexo deste mundo, mais elevado e real. E esse é o aprendizado atual da Filosofia Espírita que prega que o Universo deste planeta é simplesmente a cópia de mundos mais elevados, o Mundo Regenerativo, após o Mundo de Prova e Expiação atual. Na sequência, o homem passa aos mundos felizes e aos celestiais, a Casa de Deus, segundo Jesus Cristo: "há muitas moradas no Universo".

O Platonismo desenvolveu a ideia de que o Mundo Físico era ativamente dirigido pelo Mundo Espiritual, quando, inclusive, sugeriram uma "Alma do Mundo", espécie de Ser Divino que controlaria todo o mundo da mesma maneira que a alma humana controla o corpo. Acreditavam em alma (Espírito), uma parte do Ser humano que pertencia ao Mundo Superior e que lá iria após a morte do corpo. E muitos platônicos faziam distinção entre Alma do Mundo e um Deus Superior, a causa primária de todas as coisas.

Além de terem contato com seres elevados que habitaram há milhares de anos este planeta, os platônicos foram precursores da Filosofia Espírita, codificada mais tarde por Allan Kardec. Outra importante Escola de pensamento que se desenvolveu após a época de Platão, foi o Estoicismo. Os estoicos - chamados assim por causa da stoar ou pórtico, em Atenas, lugar de encontro para reuniões - eram célebres por sua Ética rigorosa. Eles acreditavam que a verdadeira felicidade vinha somente por meio de virtudes, não pelo prazer ou riqueza. Diferentes dos platônicos não acreditavam que poderia existir alguma coisa não-física; porém, acreditavam em Deus e que Deus pertencia ao Plano Físico, embora invisível como, também, criam em alguma coisa como a Alma do Mundo a quem chamavam Logos, significado de Princípio ou Verbo e ensinavam que esse Logos permeava o mundo com fina camada de fogo.

\section{A Religião Helenista}

As filosofias, Platonismo/Estoicismo, funcionavam algumas vezes como Religião. Elas são a base de ensino que visava explicar a Natureza humana e o seu lugar no mundo; falavam de Deus e a salvação, além de como levar uma vida moral. Todavia havia outros cultos populares, muitos herdados dos gregos atenienses. Os cultos aos deuses gregos giravam em torno de um grupo de histórias que lhes diziam respeito e sobre seres humanos que com eles interagiam. As mais importantes histórias foram encontradas nas obras de Homero e de Hesíodo, poetas gregos, cuja literatura formou o que seria essencialmente as Escrituras da Religião grega. Época de Platão e Aristóteles e mais tarde no Período Helênico, essas obras foram consideradas como história verdadeira e 
Mitologia grega pura. Os autores alegavam terem sido divinamente inspirados e que os deuses haviam falado por intermédio deles, fazendo, assim, soar suas vozes como um músico faria soar um instrumento musical, exemplo de uma flauta. Eles tiveram enorme importância no Império romano. Eram escritores de língua latina que reescreveram seus mitos e na parte do Império onde se falava grego se continuou a ensinar Homero e Hesíodo nas escolas, em conjunto com outras grandes obras do passado. Ensinavam com o propósito de instrução moral.

Homero, divinamente inspirado, acreditava-se que havia capturado em seu trabalho toda a Ética, assim como a verdade sobre os deuses, que nada mais eram do que os visitantes de outras galáxias, os quais aqui estiveram a contemplar o nosso planeta. A obra de Homero apresentou problemas, embora contenha notáveis cenas de batalhas e também mostrou o comportamento não-edificante por parte dos deuses e de heróis. Existiu defensores de Homero; por exemplo, um Autor chamado Heráclito - o nome não deve ser confundido com o filósofo - que escreveu uma defesa de Homero, na qual mostrava como cada história deveria ser interpretada, uma vez os sábios da época acharem que a obra de Homero caminhasse pelo lado alegórico. Na defesa de Heráclito, escritor do século I d.C., quando se lia que Afrodite, a deusa do Amor, cometeu adultério com Ares, o deus da guerra, deve-se interpretá-la sob a perspectiva de como o Amor pode superar o conflito no trecho da Odisseia. A crítica a Homero é advinda de mentes menos tradicionais e, na verdade, Heráclito, filósofo, havia declarado que Homero deveria ter sido punido e não elogiado por sua obra moralmente digna de repressão.

\section{A Helenização do Cristianismo}

A surpresa maior é a de que o Cristianismo existia mais intensamente no âmbito do mundo grego em parâmetro às comunidades judaicas, por volta do século II d.C. Provavelmente, os primeiros cristãos que se espalharam a ensinar a Boa-Nova se radicaram mais tranquilos e confortáveis em territórios helênicos. Nota-se que a presença de igrejas cristãs não-judaicas nas cidades do Império romano significava que os cristãos estavam se movimentando à procura de um cenário religioso mais confiável. E lembrese que era época em que cultos secretos se proliferavam; dentre eles, a de uma Religião misteriosa conhecida como Mistérios Eleusíneos proveniente da cidade de Elêusis, próxima a Atenas, cujos ritos envolviam banquetes, jejuns, celebrações litúrgicas especiais e rituais místicos tão secretos que revelá-los aos estranhos era punível com a morte. Todavia, ritos mais dramáticos eram os que envolviam o culto à Cibele, uma deusa da Frígia que se espalhou por todo o Império romano, inclusive em terras gregas.

Os cristãos à procura de novo cenário religioso inevitavelmente também mudaram no período em que o Cristianismo se tornou uma Religião mais urbana que 
rural, cujos seguidores, a princípio, falavam mais o idioma grego em parâmetro ao aramaico. Assim, o Cristianismo se tornou predominantemente uma Religião de língua grega por longo período de sua História. Embora no Ocidente boa parte do Império romano falasse latim, incluindo Roma, e muitas igrejas foram construídas por cidadãos cujo idioma predominante era o grego. Em virtude de algumas pessoas falarem o latim, pode-se entender que alguns trechos da Bíblia foram traduzidos para o latim.

Porém isso ocorreu em 200 d.C., quando se iniciou a surgir os escritores cristãos latinos. Nesse ínterim, o Cristianismo se divorcia do Judaísmo, cuja determinação como isso aconteceu não é fácil de se concluir, uma vez vários fatores contribuir a essa cisão. Um deles, o sucesso das missões cristãs, junto aos gentios nos primeiros anos, exacerbado pelo fracasso das iniciativas dos judeus, no final do século I d.C., quando havia mais cristãos entre os gentios do que entre os judeus. Outro fator, a rápida mudança adotada ao rumo do Judaísmo, principalmente no período da destruição do Templo do Monte em 70 d.C., que fortaleceu a ala farisaica do Judaísmo e à condenação temporária do Cristianismo, em 90 d.C.

Em relação à Grécia, conforme o Cristianismo se tornava menos judaico, o Estado-grego assumia perfis mais helenísticos. A rápida expansão da Religião pelo Império romano - mesmo no século I d.C. - significa que com rapidez se tornou parte da nova clássica Filosofia que era, por sua vez, o Helenismo. E em alguns procedimentos, o Cristianismo lembrava a Religião romana, época em que os romanos veneravam deuses e suas virtudes. Os cristãos veneravam àqueles que morreram pela fé. A única questão que era debatida com controvérsia nos ritos era o da Eucaristia, porque como se tornara um acontecimento litúrgico, não era mais do que um serviço eclesiástico. Nessa época, Justino Mártir ${ }^{9}$ escreveu em meados do século II d.C., para um público não-cristão

Retornando a Justino Mártir, ele discutia as pautas do dia com outros filósofos como, também, com os estudantes em Roma, onde promoveu o Cristianismo como Filosofia alternativa ao Platonismo, Estoicismo e outras. E essa sua atitude foi de enorme importância; todavia, o conteúdo dos ensinamentos de Justino mostrava mais sinais de significativa evolução em relação aos tempos neotestamentários. Enfim, época em que Paulo (Saulo) de Tarso havia pregado sobre Cristo, após a sua conversão nas areias de Damasco, Justino parecia mais interessado em Deus e suas relações com o mundo. E nesse aspecto Justino foi muito influenciado pelos platônicos e estoicos. Premissa final: de ambos se concebeu a ideia do Logos ou Alma do Mundo; uma espécie de segundo Deus que agia como intermediário entre o Deus Maior e o mundo. O Logos, segundo Justino "é um raio de Sol, distinto do Sol, mas inseparável dele". O Logos era o poder de Deus agindo sobre a Terra; mas o Logos é também Cristo. Foi como Logos que Cristo existiu antes de sua vida terrena e agora como Logos governa e dirige o Universo. A ênfase nesse Logos celestial, sua relação com Deus, o Pai, e o Mundo físico corresponde à carência de ênfase no Jesus terreno, em sua vida, morte e ressurreição. Após a morte de Justino, em 165 d.C., seu discípulo Atenágoras escreveu a "Súplica pelos Cristãos", na qual cuidou de apresentar os pensamentos cristãos sem mencionar, em momento algum, os nomes Jesus ou Cristo. Ambos escreviam para os não-cristãos e argumentavam que o Cristianismo era 
informativos, nos quais explicava que os cristãos deveriam se encontrar no início das manhãs dos domingos, o Dia do Senhor, para compartilhar esse serviço. Neles, esclareceu que quando as palavras de Jesus Cristo na instituição eram repetidas, o pão e o vinho, se transubstanciavam e adquiririam o poder de alimentar espiritualmente aos que os recebesse. Essa mensagem, décadas mais tarde é encontrada em Inácio de Antioquia, na qual a Eucaristia era a Medicina da Imortalidade.

Houve mais progresso quanto aos no que os cristãos acreditavam na medida em que as categorias da Filosofia helenística começaram a determinar o pensamento cristão e o grande personagem associado a essa mudança foi a do apologista Justino Mártir, filósofo da Escola Platônica que se converteu ao Cristianismo; inclusive após a sua conversão, Justino se considerava filósofo profissional e continuou a usar o manto peculiar da profissão.

\section{A Igreja ortodoxa}

A difusão do Cristianismo acarretou confronto entre a Fé e a Razão que, na verdade, já era esperado e Paulo, apóstolo do século I d.C., é o primeiro a enfrentar esse teorema; todavia, Paulo de Tarso estava devidamente habilitado para isso, mesmo porque seguiu os passos de Jesus em boa parte de sua trajetória, advindo a sua conversão ao Cristianismo. Ele era judeu com cidadania romana, muito elegante e belo, pertenceu ao Exército romano; foi educado em ambiente imerso na cultura helenística, falava fluentemente o grego e o latim e por isso não se intimidou quando, em Atenas, se encontrou diante de filósofos epicureus e estoicos, conforme narração do Livro de Atos, do Novo Testamento:

Senhores atenienses, tudo indica que sois de uma religiosidade sem igual... encontrei inclusive um altar com a inscrição: 'Ao deus desconhecido'. Pois bem! Justamente aqui estou para vos anunciar que este Deus que adorais sem conhecer é o Deus que fez o mundo e tudo o que nele existe.

Dentre o seu legado, as Cartas que serviram de alicerce ao desenvolvimento do Cristianismo como a Carta aos Coríntios e a Carta aos Colossenses. Destacam-se duas atitudes do personalíssimo apóstolo: a primeira, a de converter os gregos, conciliandose com os seus valores e a segunda, a de confronto, as quais coexistem nesse período

uma Religião racional, voltada para o Bem, por intermédio da Filosofia helenística, mostrando, assim, a forma de como Justino e Atenágoras realizavam as suas apresentações e/ou aulas morais. Essas tentativas de apresentar argumentos às várias crenças da época, cristãos demonstravam, em consonância às suas condições, que na verdade são teoremas a serem explicados a um mundo cético e assim representaram o início da Teologia cristã. 
inicial do Cristianismo. Todavia, o confronto corresponde a períodos em que os cristãos sofrem violenta perseguição, enquanto a conciliação representa os momentos em que o Cristianismo é tolerado. E isso deu margem aos padres apologistas, no final do século II d.C., de enviarem inúmeras apologias - defesa e justificação - do Cristianismo ao imperador. Argumentam com valores greco-romanos, afirmando, por exemplo, que Heráclito e Sócrates eram cristãos antes mesmo de Jesus Cristo.

Paulo de Tarso era de uma inteligência e perseverança inacreditáveis, tinha o comportamento semelhante ao de um repórter investigativo da época moderna. Ele não teve nenhuma dificuldade de convencer Pedro e demais discípulos de sua crença a Jesus Cristo. A mais imediata compreensão de Maria Madalena por ele merece destaque. E quando entrou nesse cenário da sua vida cristã, justamente os atenienses não o compreenderam. Em suas tentativas de exposição oral, em Atenas, ao relatar o episódio de que o Pai Todo-Poderoso havia enviado um homem para salvar a Humanidade e que, como prova, ressuscitara esse homem entre os mortos, provocou risos entre os gregos, fazendo-o a se retirar dali; todavia, conquistou uma legião de fiéis. Entre a Fé e a Razão, Paulo veio a se utilizar em suas atitudes - a de converter os gregos e a do confronto - da palavra Filosofia, quando não deixa margem nenhuma de dúvida:

Ficai atentos para que ninguém vos arme uma cilada com a Filosofia, esse erro vazio que segue a tradição dos homens e os elementos do Mundo, e não segue a Jesus Cristo. (Transcrito da Carta aos Colossenses).

Paulo de Tarso $($ Tarso $=$ nome da sua cidade natal) foi convencido a deixar Jerusalém, época em que os discípulos eram liderados por Pedro e Maria Madalena, seguidos por Tiago e João, durante o Reinado do imperador débil mental Calígula, do governador Pôncio Pilatos e sua mulher Cláudia, adepta do Cristianismo, do sumo sacerdote Caifás, acusado por todos de ser o causador da morte de Jesus. Ele volta para Tarso, onde encontra futuramente o apóstolo Felipe. Ambos trabalharam ali incessantemente na propagação dos ensinamentos cristãos.

O maior e mais controverso movimento do Cristianismo no período neotestamentário foi o do Gnosticismo. Esse tempo apresentava controvérsia entre os estudiosos sobre tudo o que dizia respeito ao Gnosticismo, a sua origem, o que queria ensinar e o que propriamente era. Eram muitos os cristãos e pagãos que se chocavam com as ideias do Gnosticismo; um dos opositores foi Irineu, cristão da Anatólia, no começo do século II d.C. Ele detestava tudo o que se relacionasse com o Gnosticismo; odiava a maneira pela qual denegriam o Mundo Material, no qual acreditava que Deus tinha ativa participação; enraivecia-se ao comentar o modo como definiam Jesus Cristo ou, ainda, pela recusa em reconhecer seu verdadeiro lado humano; por último, odiava a forma pela qual os gnósticos distinguiam entre o Deus do Velho Testamento do Deus do Novo Testamento 
e a não-percepção da importância da História cristã. Irineu acreditava que o Cristianismo se enraizava em seu passado judaico. Que Deus havia trabalhado diretamente na época do Velho Testamento e a Igreja, desde o Templo de Salomão, era a incorporação de suas promessas a Abraão, Moisés, Josué e suas famílias. Premissa final: o cristão de Anatólia, Irineu, que mais tarde se radicou em Lião (atualmente Lyon, França) representa a corrente principal não-gnóstica do Cristianismo.

\section{O primeiro patriarca da Igreja ortodoxa}

Desde a fundação de Constantinopla (hoje Istambul) por Constantino I, o Grande, em 330 d.C., até a queda da cidade, perdida para os otomanos, 1453, o Império bizantino se manteve por 1.123 anos e exatamente mais dezoito dias. Nesse período, grandes mudanças políticas e sociais aconteceram; todavia, o grau de uniformidade cultural prevaleceu por todo esse tempo de maneira extraordinária. Isso se deve ao papel central que o Cristianismo exerceu no Império. $\mathrm{O}$ elemento maior foi a quase-perfeita união entre a Igreja e o Estado, sobretudo na pessoa do imperador, visto como agente de Jesus Cristo na Terra. A sala do imperador de suntuosidade significativa, apresentava magnífico ícone de Jesus Cristo que se elevava majestosamente sobre o trono e próximo a ele outro ícone da Mãe Maria, a Virgem protetora de Constantinopla.

Em 641 d.C., novos imperadores foram coroados na Catedral de Hagia Sophia pelo patriarca de Constantinopla e aclamados com a frase. "Deus deu a nós, Deus o grande”. Uma Eucaristia se seguiria. O imperador desempenhava perfil papelchave nas grandes cerimônias religiosas do Império. Na realidade, embora não pudesse ministrar qualquer um dos sacramentos, se considerava que o imperador tinha função de sacerdote e em geral visto como o protetor da Fé. Ele convocava concílios eclesiásticos e promulgava Leis contra os heréticos. As decisões teológicas constituíam tarefa de bispos, sobretudo dos quatro patriarcas: de Constantinopla, Antioquia, Alexandria e Jerusalém, particularmente o patriarca de Constantinopla, o primeiro entre os iguais, conhecido como o patriarca ecumênico, ou seja, o líder da Igreja ortodoxa.

Nessa época, Constantinopla ainda reinava; todavia, as discrepâncias entre a Igreja ortodoxa - que iniciava uma nova era - e a sua inimiga, a cristã, já se esperava um cisma, quando a violência se espalhava por toda a Europa. Nesse clima de violência, grupos rebeldes emergiam junto às campanhas persas de Heraclio, na década de 620 d.C. Uma dramática consequência da pragmática reviravolta entre as partes divisórias da Igreja. Época em que a pena capital já não era considerada não-cristã. E essa força atinge não-só a Europa em si como, também, a Ocidental. Esses grupos têm em sua história, o período em que imperadores eram rotineiramente assassinados por aqueles em quem confiavam. Seus assassinos, em algumas ocasiões, acabavam se tornando imperadores, 
embora não sucessores legais ao trono. O próprio povo propenso à violência e muitas vezes associado às organizações desses grupos, denominados demos. Grupos organizados que não possuíam nenhum paralelo com os que hoje conhecemos; era um cruzamento entre torcedores fanáticos de futebol, partidos políticos e gangues de rua. ${ }^{10}$

Após o Concílio de Niceia, 325 d.C., convocado por Constantino e também em outras reuniões nos mesmos moldes de gênero se estabeleceu definitivamente a ortodoxia, significado de "opinião correta" da doutrina cristã. E desse processo, se desenha um cenário de muita violência contra os considerados hereges, resultando a performance da Igreja católica que, no idioma grego, significa Igreja Universal. A consolidação da Ortodoxia, no entanto, exige mais do que um ato de poder que a decrete. A Ortodoxia necessitava ser convincente, se apresentando não-somente como revelação mas, também, como resultado de raciocínios e a Filosofia patrística, oriunda dos santos padres, representa em suas vertentes esse esforço de munir a Fé de argumentos racionais. Nesse elenco, Santo Agostinho é quem desenvolve a conciliação entre a Fé e a Razão, elaborando a Filosofia cristã, conforme ele a chamaria.

\section{O surgimento dos mosteiros gregos}

Na busca da felicidade eterna, homens se agregam imbuídos de filosofia pura e própria, surgindo, assim, famosos mosteiros; um deles se desenvolveu na Região de Meteora, Norte da Grécia, onde as Montanhas Pindus davam passagem às planícies

10 Existiam dois grupos denominados "azuis" e "verdes"; todavia, outros grupos menores e menos poderosos - os "vermelhos" e "brancos" - faziam parte do elenco, cujos nomes eram originários da cor das carruagens (bigas) das equipes para os quais torciam. O ponto de encontro era o Hipódromo, a principal área esportiva e centro da vida social na cidade de Constantinopla. [Essa área existe ainda hoje nas cercanias da Santa Sophia e da Mesquita Azul; atualmente ponto turístico de Istambul, cujo privilégio meu foi o de conhecer em visita à Turquia.] Os "demos" podiam provocar tumultos entre os quatro grupos ou a se unir contra imperadores não-populares ou, ainda, mediante suas políticas implantadas. Em 532 d.C., um desses tumultos no Hipódromo durou mais de uma semana, destruindo edifícios da cidade, o que assustou o imperador Justiniano, a ponto de fazê-lo pensar em fugir da capital; o que não aconteceu dada a interferência da sua mulher, a bela e valente Teodora que o persuadiu a ficar. Até então, o imperador e sua esposa Teodora apoiavam os "azuis"; porém, os insurgentes foram barbaramente massacrados, atingindo cerca de mais de 30 mil pessoas mortas. Justiniano aproveitou o episódio de destruição causada pelo tumulto iniciando novo programa de edificações, uma vez vir a se dedicar à criação de esplêndidos monumentos, sendo o mais famoso o da Igreja Hagia Sophia "a Santa da Sabedoria", originariamente construída por Constâncio, um dos três filhos de Constantino em 360 d.C., e reconstruída em 415 d.C. Era uma igreja aos moldes basílicapadrão, destruída pelos baderneiros em 532 d.C. O imperador estava destinado a construir algo pomposo e mais ambicioso; sendo assim contratou dois dos melhores arquitetos da época chamados Antêmio de Trales e Isidoro de Mileto, orientando os arquitetos gregos a não se preocuparem com as despesas, o que eles não o desapontaram junto a uma equipe de mais de 10 mil operários, a maioria de origem grega, que trabalhou durante cerca de cinco anos na construção da mais bela e a maior igreja quadrada, coroada por uma cúpula jamais vista no mundo. No término da obra, Justiniano se comparou a Salomão, declarando: "Salomão, eu vos superei!" 
da Tessália. Ali grandes rochas afloravam das planícies e sobre estas no século IV d.C., inúmeros mosteiros foram sendo erguidos, criados por esses grupos agregados. Eram construídos em montanhas inacessíveis, a ponto de, pela manhã, muitos monges descerem por meio de cordas para trabalhar; à noite, puxados pelos demais integrantes para subir ao aconchego. De todos, o mais famoso foi o Mosteiro dos Montes Altos, localizado em uma península ao Norte da Grécia. Esses mosteiros prevaleceram até o século XI, em cômputo numérico de mais de 7 mil deles existirem.

Ressalta-se que eles fugiram da conturbada vida urbana das cidades e se contemplavam na palavra de Deus; a maioria seguia a orientação espiritual de João Clímaco, conhecido como "João da Escada", escritor do século VII e Autor de Escada da Perfeição, obra na qual descrevia a escalada da progressão da vida dinâmica para uma vida contemplativa, sugerindo em seus textos que se sobe na escada até Deus, erradicando-se o vício e se adotando, aos poucos, às virtudes apresentadas por Ele. Entretanto a escada da perfeição deve ser conquistada galgando-a muito devagar. Trata-se de um processo difícil, no qual se deve entrar com absoluta consciência; porém, a crescente percepção de Deus que o processo produz, torna mais fácil seguir à frente e vai ficando cada vez mais claro que todo o trabalho é realizado pelo próprio Pai Todo-Poderoso em sua eterna graça divina. Por meio de altas labaredas de fogo - o que assusta a maioria -, a imagem de Deus se apresenta ao devoto, nos mesmos moldes que acontecera aos profetas da Antiguidade. A meta final é a contemplação de Deus, Autor da Lei do Amor. Muitos julgavam a obra de João Clímaco profundamente inspirada pelos Espíritos de Luz, ou seja, mediunidade na escrita. E os escritos são até hoje recomendados como leitura na Quaresma nos âmbitos dos mosteiros ortodoxos, uma vez nesse período grande parte da Grécia se tornar adepta do Cristianismo ortodoxo.

Por último, João Clímaco antecipou uma forma de misticismo associada ao Montes Altos conhecido como Hesicasmo, termo derivado da palavra grega que tem o significado de "quietudes". O Hesicasmo se desenvolveu devido à procura da apatheia ou ausência de paixão, lembrando o Estoicismo. Os monges visavam atingir esse estado, sem paixão, por meio do domínio da mente e, ao mesmo tempo, do corpo concebidos como uma unidade; se utilizavam de técnicas respiratórias e preces repetitivas para adquirir um estado de auto-hipnose, por meio do qual a mente poderia ser completamente esvaziada de pensamentos e neste comportamento se acreditava ser capaz de visualizar Deus! Em um dos trechos de uma prece, conhecido como Oração de Jesus, deve ser atribuída a João Clímaco: "Jesus, Filho de Deus, tenha piedade de mim, um pecador". Trecho pronunciado em forma básica durante a reflexão. 
Enquanto o calendário juliano se apresenta com treze dias de atraso em parâmetro ao nosso, cerca de milhares de monges do Monte Santo Áthos ${ }^{11}$ não têm pressa nenhuma à margem do ritmo do Mundo. Os primeiros ermitões do Cristianismo que, no transcorrer dos séculos, construíram significativos mosteiros fizeram com que o Hagion Oros ou Monte Santo se tornasse o centro espiritual da Ortodoxia.

Por mais de um século, monges se utilizaram de ícones como parte integrante de suas devoções e eles não tinham a intenção de abandoná-los. Outro líder famoso foi Estêvão, do Mosteiro de Santo Auxentius. Ele foi jogado na prisão por acusações fraudulentas e forjadas. As acusações, dentre elas, a de que, por meio de propaganda oral, incitava jovens à adesão do Monastério. E em 761 d.C., um monge chamado André de Creta (não o Autor dos hinos gregos) foi chicoteado até a morte por denunciar Constantino V como "um novo Juliano, o Apóstata", tornando-se o primeiro mártir dos ícones. Após a morte de André de Creta, Estêvão foi arrancado de uma cela por uma multidão e assassinado por apedrejamento. $\mathrm{O}$ imperador Constantino $\mathrm{V}$ foi inflexível em relação à oposição monástica, humilhando-os, ordenando a serem atacados e aprisionando-os. Os ícones foram confiscados e destruídos. Os monges foram obrigados a se casar e o patriarca de Constantinopla, vegetariano, forçado a comer carne e a escolher uma esposa. A Religião bizantina, adepta por grande parte da civilização grega, se desenvolveu ao redor dos polos gêmeos - Igreja/Estado -, unidos na concepção bizantina como um todo e sob esse aspecto não se surpreende que a Igreja ortodoxa bizantina não se desse muito bem com as outras Igrejas, uma vez que, se o imperador era o regente de Cristo na Terra, como se situariam os cristãos que não estivessem debaixo desse governo?

Relembra-se que a Grécia se converteu em Província romana em 146 a.C. O Exército romano era uma máquina defensora de toda a Europa antiga, não-só na defesa como, também, na organização social, constituída por legião de homens militares portadores de conhecimentos da engenharia civil, hidráulica - inventaram os "qanatis" (aquedutos) junto aos visigodos (que a destruiu) - e arquitetônica apresentando arcos e tetos abobadados, característica marcante da arquitetura antiga. No elenco, Roma computava

11 A origem do Monte Santo Áthos e demais blocos se remonta ao Período Terciário, no qual uma torrente de montanha desembocou em um braço do Mar Tessálico, acarretando arrastamento dos escombros que fechavam à desembocadura. Mais tarde, o Rio Pínios foi abrindo caminho até o Mar Egeu, deixando para trás um conglomerado de arenito que a erosão e os rigores meteorológicos se encarregaram de modelar. E desses fenômenos geológicos resultaram gigantescos blocos de pedra coroados por plataformas (ou pináculos), que chegam a alcançar 100m de altitude, formando singular paisagem no Vale do Rio Pínios. Essa escarpada e grandiosa paisagem rochosa se constituiria em lugar de retiro ideal para ermitões que, cansados da turbulência surgida entre Igrejas, desejavam se dedicar às orações e à vida contemplativa que eles próprios achavam merecedores. Esses primeiros homens se instalaram em covas e grutas na base das rochas de Meteora e, a partir daí, surgiu a Igreja Mariana de Deupiani e o lugar recebeu o nome de "stus hagious", significado de "aos santos". 
em sua civilização geográfica cidadãos de natureza grega até a sua queda em 410 d.C. Após a queda da Cidade Eterna e arredores, a Europa mergulhou em um caos por cerca de 1000 anos. Em 1340, o príncipe sérvio Esteban IX Duskan conquistou a Tessália e se proclamou Rei dos sérvios e dos gregos. ${ }^{12}$ Nesse período agitado de turbulências políticas, os eremitas gregos se transferiram para os cumes de Meteora, na busca de mais proteção e em seu esplendor a Região de Meteora chegou a possuir 24 mosteiros, aos quais príncipes e patriarcas haviam concebidos enormes privilégios. Logo em seguida, a Sérvia declinou.

Atualmente, somente quatro destes mosteiros contêm atividades e ainda seguem oferecendo fiel testemunho da disciplina monacal ortodoxa que, além de vigorar nos dias de hoje, proporcionam fascinante visão da arte sacra pós-bizantina.

\section{A Criação do Estado-grego}

Não há registro de quando o homem apareceu pela primeira vez na Península grega, embora haja amostras de ossos de animais junto aos utensílios paleolíticos, testemunhando sua existência no Paleolítico Médio entre $100 \mathrm{mil}$ e 33 mil anos. É contabilizado cientificamente que o homem sábio, Homo Sapiens, apareceu há 100 mil anos antes munidos de ferramentas de pedra e novas técnicas mudando, assim, radicalmente o curso da Humanidade. Cumpre salientar que as grandes mudanças climatéricas ocorridas por volta do nono milênio com a deslocação dos glaciares influenciaram de maneira dramática a vida do homem, criando condições para a Revolução Neolítica quando, no sétimo milênio, o homem começou a se ocupar da agricultura, da criação de gado, além de viver em povoados organizados, a exemplo de Nikomidis, Sesclo, Demini e também outros locais da Grécia.

Em 2800 a.C., a Grécia foi contemplada com o uso de metais, enfatizando o cobre e em consonância à tradição, na Região grega, viviam os pelasgos, os cares e os ledeges, classificados como tribos pré-gregas. Outras tribos da Ásia Menor se instalaram em Creta; delas, a criação da civilização minoica, a mais antiga da Europa. Dessas cidades, se desenvolveu outra civilização independente: a cicládica. Junto a esta

\footnotetext{
12 A Igreja Ortodoxa sérvia/grega se tornara importante instituição nos Balcãs setentrionais com seu patriarcado próprio localizado em Peae, no Sul da moderna Sérvia. Grandes catedrais e mosteiros foram construídos pelo Reino sérvio nos séculos XIII e XIV d.C. Todavia, os otomanos aniquilaram a área em 1389 e a Igreja Ortodoxa sérvia/grega começou a declinar. Das práticas horrorosas e prejudiciais dos otomanos, o rapto de crianças e jovens escravizados e forçados a se educar como muçulmanos. Esses jovens - educados como propriedades do sultão - poderiam alcançar as mais altas posições no serviço público ou, ainda, nos recintos governamentais. Outros eram recrutados ao Exército otomano pertencentes a uma força-de-elite. Isso acabou esvaziando o propósito da Igreja Ortodoxa sérvia/grega da sua juventude e embora nunca tenha morrido, perdeu o vigor. Os sérvios cristãos fugiram deixando vidas e cidades em direção às montanhas gregas, assentando comunidades pequenas voltadas à agricultura no intuito de sobrevivência. Essas comunidades, com o passar dos tempos, se tornaram cidades e cidadãos gregos.
} 
civilização, floresce ao mesmo tempo a civilização helênica: aqueus, jônios e eólios que foram as primeiras tribos gregas de origem indo-europeia, por volta de 2000 a.C. Deste conglomerado, a primeira autêntica civilização grega, a micênica entre 1580 a.C. - 1100 a.C., quando, na trajetória, em 1400 a.C., os aqueus ocuparam Cnossos, expandindo-se pelo Rodes e Chipre, fundando portos comerciais na Ásia Menor. Eles criaram relações diplomáticas com os egípcios, assírios e hititas. Empreendedores, construíram palácios em colinas fortificadas mediante levantamento de muralhas ciclópeos, desenvolvendo no interior série de setores da Arte grega antiga. A destruição da civilização micênica foi causada pelos dórios no século XII a.C., período conhecido como a Idade Obscura grega.

No século VIII a.C., a criação das cidades-Estado; no elenco, Atenas, Mégara e Tebas, governadas por Reis, perante concelhos aristocráticos, as oligarquias. Os conflitos sociais e as agitações políticas criaram a necessidade de reformas legislativas como as do legislador Licurgo de Esparta, Drácon e Sólon, de Atenas; apesar da separação em cidades-Estado e dos conflitos entre as mesmas, os gregos mantiveram a consciência da união nacional, por meio do idioma comum, da instituição dos Jogos Pan-helênicos em Olímpia, Pítia, Istmia e Nemea, dos santuários das Anfitionias, o que quer dizer: das reuniões dos representantes das cidades-Estado. O conjunto se intitula Época Arcaica.

À Época Arcaica, o florescimento da Arte e da Ciência, a construção de grandes templos de ordem dórica e jônica - com o aparecimento de enormes estátuas, de komos e kore -, além da cerâmica negra; mais tarde, a encarnada. Ao mesmo tempo nasceu a Filosofia. Em 494 a.C., Dário reprime a rebelião do Rei Ciro, oriundo da Ásia Menor que havia se decidido a invadir Atenas. Em 490 a.C., os persas tentam invadir todo o território grego com 50 mil homens que chegaram à Planície de Maratena. Dez anos depois, 480 a.C., Xerxes, filho de Dário, prepara nova incursão contra a Grécia, junto a um Exército inumerável e 1,2 mil barcos. No desfiladeiro de Termópilas, Leonidas tenta parar a invasão munido militarmente de 300 espartanos e 700 tespies. Todos os gregos morreram nesta sangrenta batalha! E neste lugar existe hoje um monumento que recorda aos visitantes turistas este famoso sacrifício, por parte da civilização grega.

O Exército de Xerxes dizimou Tespies, Plateas e chega à Atenas. A cidade, com a sua Acrópole e os poucos atenienses que ficaram, se deparou envolta às chamas em quadros dramáticos de sobrevivência. Em 479 a.C., gregos unidos - sob o comando de Pausanias - derrotaram os persas na Batalha de Plateas, quando morre o general Mardonio, um dos maiores e inesquecíveis defensores da Grécia. Em 477 a.C., Atenas arquiteta uma aliança com mais de 300 cidades, cuja sede era no Santuário de Apolo, em Delos, conhecida como Aliança de Delos, período em que se inicia a imensa reconstrução dos monumentos da Acrópole, destruídos pelos persas. É o Século de Ouro, de Péricles, durante o qual o florescimento conjunto da Filosofia, da História e do Teatro. 
Advém a Guerra de Peloponeso, 431 a.C., com a Grécia dividida que se expandiu por toda a região grega e durou exatamente 27 anos! Acabou em 404 a.C., com a vencedora Esparta que impôs às cidades um governo totalmente autoritário. Mas não durou muito, porque dois militares políticos de Tebas - Pelopidas e Epaminondas -, defenderam os não-espartanos e humilharam os espartanos, 371 a.C., em Leftra de Beócia e em 362 a.C., em Mantíneia de Arcadia, terminando, assim, o domínio de Esparta, substituindo o domínio tebaico em quase toda a Grécia. Após a morte de Pelopidas e Epaminondas, desapareceu a glória de Tebas. Entra em cena mais tarde o Rei Filipe II, da Macedônia, que tinha concebido a ideia de unir todas as cidades-Estado gregas em um único Estado, sendo motivo da IV Guerra Sagrada, 339-338 a.C. O Rei Filipe, político, interviu, castigou a população de Anfisa e prosseguiu para Queronea, onde derrotou os atenienses e os tebanos que se tinham aliado contra ele. Em uma conferência pan-helênica - convocada pelo Rei da Macedônia - foi acordado que a Liga pan-helênica, na qual o Rei Filipe seria o responsável em expedição contra os persas. Dois anos depois, o Rei foi vítima de uma conspiração palacial e assassinado por seu oficial de confiança, Pausania.

Seu filho, Alexandre, aos 20 anos de idade foi encarregado de realizar os planos ambiciosos do seu pai e em pouco tempo reprimiu as revoltas tanto das ideias quanto das cidades gregas; convocou mais duas conferências pan-helênicas, em Corinto, e renovou a Liga pan-helênica. Considerado um dos homens mais belos que existiu neste planeta, o jovem Alexandre começou a expedição para a Ásia com seu famoso Exército e a Marinha contra os persas. Em dez anos defendeu muitas vezes seu contingente dos persas, conquistou a Ásia Menor, Síria, Palestina, Egito e chegou ao Vale do Rio Indo. Por toda a parte fundou muitas cidades gregas, as quais se tornaram integrantes da civilização grega, sendo a mais destacada a de Alexandria, Norte do Egito. Morreu jovem, aos 33 anos em 323 a.C., quando o vasto Império fora dividido em Reinos destinados aos seus generais. À época seguinte: a Helenística!

Os conflitos entre os Reinos todavia nunca pararam e o mesmo acontecia no interior da Magna Grécia, surgindo, posteriormente, duas alianças de cidades: a Confederação Aquea, em Peloponeso, e a Confederação Etólia, na Grécia Continental, cujo objetivo maior era o de conseguir enfrentar e fixar os planos expansionistas dos macedônios. Esses conflitos civis internos permitiram que Roma interviesse nos problemas internos gregos. A conquista da Grécia pelos romanos foi muito rápida, iniciada com a batalha em Kinos Kefale, 197 a.C., onde Tito Quinto Flamínio derrotou Filipe IV, da Macedônia. Continuou, também, com a derrota do Rei da Pérsia e o da Macedônia por Pávlo Emílio em Pidna, 168 a.C., e culminou com a destruição de Corinto por Léfquio Mómio, em 146 a.C. A Grécia se tornou uma Província romana e durante o domínio de Roma, o Estado grego sofreu série de catástrofes, enfatizando Atenas, quando Silas, 86 
a.C., saqueou e massacrou a sua população; todavia, o esplendor da civilização grega influenciou os romanos.

Nos séculos III e IV a.C., a Grécia sofre outras derrotas pelas incursões bárbaras dos godos e dos herúlos. Aos meados de 330 d.C., o imperador Constantino funda Constantinopla que se torna a Capital cristã de todo o Império. Neste período centenas de obras importantes de toda a Região grega foram transportadas para a Nova Roma, sendo iniciada nova época da História grega. Atenas, ao longo da História da Humanidade, sempre ostentou com orgulho a grandiosa Acrópoles em todos os acontecimentos importantes acontecidos; o monumento sempre esteve presente. Em 2000 a.C., os jônios a fortificaram após o desaparecimento dos pelagos. A Acrópoles na época do Rei Cécrope tinha o nome de Cecrópia, quando se estabeleceu o culto da deusa da Sabedoria, Atena, em lugar de Poseidon, deus do Mar. A partir daí a cidade tomou emprestado o nome da deusa da Sabedoria e foi definitivamente nomeada Atenas. ${ }^{13}$

Os herdeiros de Cécrope, Pandíon, Erecteu, Egeu e Teseu governaram com sabedoria e contribuíram para o desenvolvimento da Grécia e todos viveram no Palácio que se situava sobre a Acrópole; alguns deles foram enterrados neste mesmo local. Teseu, mítico, foi glorificado com muitos feitos e libertou a cidade de Atenas de tributo de sangue que pagava à Mínoa de Creta, dominador do Mar, matando o Minotauro como narra o mito, tornando a cidade de Atenas a capital da Região grega, cuja maior celebração são as festas das Panateneias até os dias de hoje. O último Rei ateniense foi Codros que - em consonância com a tradição - sacrificou com heroísmo a sua vida para salvar a cidade dos dórios. Após a sua morte, a Monarquia foi abolida e a Aristocracia implantada, dando sequência à vida social, mas não conseguiu resolver a diferença entre os aristocratas e os agricultores pobres.

13 O esplendor do seu passado, as Escolas famosas de Arte e de Filosofia perduram imortais. Em 529 d.C., o imperador Justiniano fechou todas as Escolas gregas e acabou também com a glória de Atenas naqueles períodos que, com o passar dos anos, se tornou em pequena cidade provinciana, mas teve suas invenções jamais superadas como exemplo os barcos gregos - um deles batizado com o nome "Quarenta" de 40 mil metros, remado por contingente de mais de 4 mil homens, jamais visto em toda a História da Humanidade. Embora as aventuras interferidas de Bizâncio e da ocupação turca, Atenas foi somente nomeada oficialmente a capital da Grécia em 1834. Neste período, começaram as obras de restauração e de limpeza da Acrópoles na tentativa de cicatrizar algumas fendas deixadas pelas guerras, o que gradativamente foi conseguido, qualificando-a como uma das mais belas cidades do mundo e, ainda, que ressurgisse mais gloriosa. Ela é o orgulho da Humanidade até os dias modernos deste século XXI. Atenas e suas ilhas foram desenhadas por vulcões que erigiram lugares de cenários deslumbrantes e inesquecíveis aos olhos de um número infindável de turistas que a visitam, a maioria sentindo vontade de nunca mais sair dela. 
8. O surgimento do Direito

No século VI a.C., as agitações políticas continuavam em efervescência, quando surge na vida política grega o sábio Sólon que, por sua vez, introduziu uma Constituição, cujo conteúdo de normas jurídicas do diploma resolvera o problema das dívidas dos pobres para com os ricos. A sua legislação continuou a vigorar quando Psístrato subiu ao Poder em 560-527 a.C. Sólon, embora tenha governado Atenas como tirano apoiou e muito os pobres. O princípio do final da tirania foi assinalado pela execução de um dos filhos de Psístrato, Hiparco, pelos tiranicidas Harmódio e Aristogiton, de família nobre, os Alcménidas. Desta família provinha também o legislador Clístens que, em 506 a.C., modificou e completou a Legislação de Sólon, fundando a Democracia ateniense. Sólon se posiciona na categoria jurídica do mais sábio legislador constituinte. Em 461 a.C., Péricles foi eleito à governança de Atenas e assim o fez até a sua morte em 429 a.C. Ele consolidou o sistema democrático que é referência não-só ao Direito Romano de Justiniano como, também, no futuro aos países integrantes do Estado Democrático do Direito. É incontestável que a maior obra do pensamento romano é o Direito, uma vez vestido de caráter técnico e impessoal, obtendo uma forma coerente e sistemática de maneira que cada parte não conflite com as demais mas, neste sentido, o Direito Romano é herdeiro do pensamento abstrato dos gregos no ideal de um todo harmonioso e muito bem-proporcionado.

Cumpre salientar que antes do Período republicano romano, a Lei se confundia com preceitos religiosos e se baseava no Direito Consuetudinário, ou seja, aos usos e costumes. No início do Período republicano não foi diferente, uma vez as repetitivas revoltas de plebeus por mais direitos tornarem necessário o estabelecimento, por escrito, de Leis básicas e o resultado foi a Lei das Doze Tábuas, em 450 a.C., a qual abrangia o Direito Civil, o Direito Privado, o Direito Penal e certos aspectos do Direito Público que, de maneira geral, equiparava, juridicamente, os plebeus aos patrícios. Também neste Período, se multiplicaram outras Leis e se desenvolveu a Jurisprudência, Ciência do Direito, que examina a aplicação de normas abstratas aos casos concretos. Surge também a figura dos jurisconsultos, os quais forneciam consultas públicas aos que recorressem à Justiça. O Senado monopoliza a iniciativa de proposição das Leis, antes compartilhada entre Assembleia e Senado. Mas na prática era prerrogativa do imperador. O Direito se torna menor em assuntos políticos, facilitado pela sistematização das Leis empreendidas por Justiniano que formou comissões de especialistas, os quais compilaram as Leis existentes, reduzindo-lhe o número e as tornando compatíveis entre si: o resultado é o Corpus Iuris Civilis, coleção de quatro compilações que até hoje constitui a base da Legislação grega e de quase todos os países civilizados em suas discussões reflexivas. 
Para Aristóteles em Ética a Nicômaco, o Direito é um conjunto de regras de conduta que aos homens cabe obedecer em sua vida social, a fim de que possa ser, nela, respeitada a sua Natureza. Desta forma, o fim do Direito é assegurar que, a vida social, cada homem possa encontrar aquelas condições para realizar o seu Ser. O Direito procura dar a cada um o seu. Dar a cada um o seu é a definição de Justiça, porque o Direito tem por objetivo a Justiça, algo vinculado à Natureza humana e serve a esta dar a cada um o seu: essa repartição é o Direito que procura fazê-lo, de modo que reine igualdade entre todos. Sucede, todavia, que essa igualdade na Justiça não quer dizer igualdade cega, tratar todos os indivíduos e situações como se fossem idênticas. A igualdade da Justiça é uma igualdade proporcional. Essa igualdade proporcional, o Direito procura realizá-la de duas formas: realizando a Justiça Comutativa e a Justiça Distributiva. Pela primeira (Comutativa), visa obter que, nas relações de troca, haja igualdade nas proporções dos bens negociados: coisa e preço, trabalho e salário, etc. Pela segunda (Distributiva), visa obter que a repartição dos bens e dos encargos do Estado seja feita em proporção às necessidades e aos méritos de cada um. Logo, tanto em um quanto em outro fica partilhado a cada um o seu.

Ao Direito Natural que Aristóteles chamava de Justo Natural se podia dizer que os entes desse mundo se desenvolvem de acordo com a sua Natureza ou, ainda, que agem em consonância com a sua Natureza; ou que procuram realizar as potencialidades de sua Natureza ou Forma. Com isso podia, também, dizer que cada Ser se desenvolvendo de acordo com a sua Forma, tinha por objetivo ou fim (telos, teleologia) realizar a sua Natureza. A conclusão só pode ser a de que é realizando a sua Natureza e seguindo as inclinações desta é que o Ser se realiza e atinge o seu objetivo: a plena realização de si mesmo! Eis o que é o Direito Natural: aquele conjunto de prescrições, emanadas da Natureza do homem e que este deve seguir, a fim de atingir a sua existência que é a realização de suas potencialidades!

Conclusão

Na História da Civilização, existiu um povo na busca do Saber, ponto culminante no processo da vida, que procurou algo que fosse o Princípio e o fundamento de todas as coisas (arthé), palavra grega que se assemelha - em seu significado - à espécie de semente universal - a bela tâmara - e o telos, o germinar, o crescer, o fortificar até o desaparecer... esse povo pertence à Região grega, os helênicos! Esta conclusão é o conjunto dos estudiosos especialistas da História da Civilização que têm como ponto de partida os séculos VI e V a.C., período testemunho da existência do homem de inteligência avançada como Buda, Lao-tsé e Sócrates da Grécia. Os gregos nos repassaram que a glória não se trata de vaidade, mas o caminho correto de nós nos assemelharmos aos deuses; traduzindo: sempre existir pela vivência, tendo como princípio o de nunca deixar 
de parar de andar pelo trilho mágico (o livre arbítrio) escolhido por nós. Os gregos nos ensinaram a sempre nos preocuparmos com o futuro, por meio da preservação que se constituirá um legado de registros à eternidade. Dentre as preservações, a mais famosa: traduções do Antigo Testamento, a Torá, realizada por volta do século III a.C., para a língua grega, o idioma mais influente na época, cuja versão bíblica foi encomendada pela Biblioteca de Alexandria, o maior centro cultural da Antiguidade. [Embora nunca olvidar da Biblioteca de Bagdá, destruída estupidamente na invasão dos mongóis; um desastre inestimável à História dos Povos quanto à perda de acervo de milhares de livros, lançados às águas dos rios da cidade, deixando-os escurecidos na cor preta causada pelas capas que os protegiam. A Biblioteca continha registros históricos da Mesopotâmia e da civilização mais antiga pela escrita, os sumérios].

Pesquisadores apontam que o trabalho de tradução para o idioma grego mereceu obra de 72 tradutores judeus, a pedido do governador Ptolomeu II, de origem grega. Essa versão ficaria conhecida como a Septuaginta ou $L X X$ e que até hoje é a base da Bíblia, usada pela Igreja ortodoxa grega. Cumpre salientar que a versão da Bíblia hebraica para o grego gerou a primeira grande polêmica, mérito das divergências fora as próprias traduções. Premissa final: nada importa, além da preservação para a Magna Grécia. Também se enfatiza que o manuscrito mais antigo que contém a íntegra do Novo Testamento foi encontrado, 1844, em um mosteiro no Monte Sinai, datado do século IV d.C., comprovado por teste carbônico e esse manuscrito fora escrito em idioma grego: uma evidência de que o cânon já estava praticamente fechado, neste período. $\mathrm{O}$ manuscrito tem o formato de códice, ancestral do livro moderno, revelando, assim, a preferência dos cristãos pelo uso da nova tecnologia no lugar dos velhos rolos de papiro ou pergaminho. Segundo os pesquisadores, o uso do códice foi vantagem na difusão dos textos cristãos, tornando-os mais fáceis de serem manuseados em comparação aos enormes rolos antigos. A nova técnica possibilitava, pela primeira vez, a inclusão de todas as Escrituras em único volume, dando unidade às narrativas bíblicas.

Enfim, a maneira de pensar e de se conceber a origem do Universo se desenvolveu na Grécia clássica; na época, um mosaico de pequenas comunidades independentes que se espalhava junto ao Mediterrâneo, desde a Jônia, na Ásia Menor até o Sul da Itália (Sicília), tendo no centro a Grécia propriamente dita. A Grécia passou a ser ocupada em 1600 a.C., por um povo a quem o poeta Homero os designou de aqueus, os quais ergueram enormes edificações em Micenas, Tirinto e Pilos que guerreavam entre si. Micenas foi a vencedora, quando vieram os dórios em 1150 a.C., se estabelecendo em Epiro, Etólia, Arcânia, Peloponeso, Creta e Anatólia. Outros povos como beócios, tessálios e trácios entraram em territórios da Grécia. Dessa miscigenação, a origem da pólis, uma nova forma de organização social e política, cuja característica a supremacia do Logos, significado de discurso e Razão. Entre os séculos VIII a V a.C., a sociedade 
grega se empreende na busca ao encontro de sociedade justa e de um pensamento racional e livre de preconceitos. Nesta tentativa se originam a Democracia e a fantástica Filosofia.

Os gregos nos ensinaram o respeito mútuo e a Ética no complicado relacionamento humano, por meio das pequenas comunidades, de homens agregados que viviam em diversas tribos, cujo fruto o gigante Estado em ambiente que proporcionou ao mundo filósofos que se tornaram lendas... e as lendas não desaparecem, são imortais, eternas. E cabe aos escritores de História e Filosofia não deixar que essas lendas desapareçam. Acredito que estiveram conosco para a nossa evolução terrena em parâmetro a mundos de seres de inteligência avançada. Eles foram prodígios pela mediunidade em contatos extraterrenos, a exemplo de Platão; ele próprio asseverava essa iluminação vivida em meio a seres estelares.

Os gregos acreditavam em deuses/deusas com forma humana; dentre eles, Zeus que chamavam por Thelos, significado de Deus. A ideia de um Deus Único, vinda de habitantes da antiga Grécia... e antes de Jesus Cristo! Aonde estiverem, que se sintam orgulhosos dos trabalhos produzidos neste mundo; dentre eles, o instituto da Democracia. E dentre as prerrogativas no pensamento desses filósofos gregos, o de se indagar sobre tudo da origem das coisas e da Natureza na criação da palavra physis. Mas o sentido da physis é muito mais amplo, uma vez se referir à realidade (não a pronta e acabada), mas a que se encontra em movimento e transformação: a que nasce e se desenvolve. Nesse sentido, a palavra significa gênese, origem e manifestação. Entender ou saber o que é a physis acarreta a questão da origem de todas as coisas que constituem a realidade, que se manifesta no movimento; procura, também, saber se existe um Princípio Único, arkhé que, por sua vez, quer dizer comando, o que dirige e ordena todas as coisas do mundo em seus diversos e contraditórios aspectos.

Por meio desses temas que se ocuparam os primeiros filósofos gregos, embora pouco se saiba a respeito desses pioneiros do pensamento ocidental; infelizmente, de seus textos restaram poucos fragmentos e estes devidamente catalogados e protegidos na Biblioteca de Atenas. Suas ideias chegaram por meio das versões apresentadas pelos pensadores posteriores. Os posteriores pensadores vieram da Jônia, pequena colônia fundada na Costa asiática grega pelos micênios, os quais se refugiaram das perseguições e invasões dóricas.

Quanto aos jônios, estes desenvolveram atividades comerciais e artesanais que favoreceram o surgimento de novos valores sociais, baseados não-só na tradição mas muito mais na iniciativa dos indivíduos e, assim, a vida cultural floresce, cuja obra de Homero é testemunha. A Astronomia e a Matemática se desenvolveram sob a influência 
dos contatos com povos do Oriente. ${ }^{14}$ Com o passar dos tempos, a cidade de Mileto se impõe como o centro cultural principal da Jônia e neste espaço físico grego o aparecimento dos pré-socráticos: Tales, Anaximandro e Anaxímenes, os quais recebem essa nomeação porque vieram antes de Sócrates e qualificados como marco da Filosofia ocidental. Eles são os fundadores da Escola de Mileto, a primeira referência em estudos não-só filosóficos como em outras áreas à formação de futuros acadêmicos. Discrepâncias havia em seus raciocínios; todavia, são unidos pelo fato de terem inaugurado a Filosofia com a mesma significativa pergunta: o que é a physis? Mais tarde, por esse motivo, Aristóteles denominá-los physiologoi, fisiólogos $=$ os estudiosos da physys $!^{15}$

São Paulo, fevereiro de 2017.

14 Dentre os contatos orientais, o exemplo dos assírios e caldeus (4000 a.C.) que estruturaram nova visão ao mundo que perdurou até Zoroastro (ou Zaratustra), propondo a existência de um Deus Único, no século VIII a.C., ou na Índia por meio dos "Vedas" ("Livros do Saber"), os quais influenciaram as mentes em 1500 a.C., seguido do Hinduísmo, Bramanismo e Budismo que vieram no século VI a.C. Por último, a China premiada pela Dinastia Chang, introduzindo transformações culturais em 1600 a.C., mais tarde assistindo a expansão do misticismo do Tao e a sistematização religiosa-política-familiar de Confúcio, transformando e amoldando a sociedade tradicional chinesa de maneira peculiar nos séculos seguintes. Ideias divergentes tendem a convergir a mundos confortáveis!

15 Os gregos têm passado dos mais significativos no transcorrer da História da Humanidade; dentre relatos passados, o da Era ptolomaica, uma vez estrangeiros governando um Império egípcio constituído de enigmáticas tradições. A Rainha Cleópatra, de descendência grega, foi a última da Dinastia faraônica: bela e inteligente, sua imagem é cravada e até hoje contemplada nas paredes do Templo de Dendara, Sudoeste egípcio, obra iniciada pelo pai, o faraó Ptolomeu XII. Nos percalços de sua governança de amores conturbados, envolvidos com Júlio César e Marco Antonio, terminou com a própria vida, suicidando-se; todavia, alcançou a imortalidade. Os gregos radicados em Alexandria colaboraram à evolução da mente inteligente não-só pela construção da maior e luxuosa Biblioteca daquela cidade como, também, no desempenho dos trabalhos de verdadeiros gênios, a exemplo de Philo, Heron e Archimedes, inventores de legado até hoje utilizados pelos cidadãos modernos. O inventor tem de ser humanista, no intuito da colaboração de um mundo melhor e, assim, os gregos fizeram. Dentre os inventos, o Raio da Morte, arquitetado por meio da luz do Sol, a criação do parafuso, a máquina de compras, a porta automática pela pressão do ar, o sistema de polias à velocidade da água para irrigação. Todos esses inventos são obras do trio assinalado. [Na época moderna, Nicola Tesla, dos EUA, basicamente o responsável pelo mundo evoluído atual, inventor da bomba elétrica gigante]. No Deserto de Baharyia, Sudoeste egípcio - onde foram encontradas pelos arqueólogos cerca de 10 mil múmias cobertas de ouro -, os gregos ergueram junto aos nativos a cidade de Baharyia, local de moradia das elites grega e egípcia; nela, a gigantesca estátua de Ísis, esposa de Osíris. Do conjunto do Arquipélago Eólias, Sicília que pertencia à Coroa espanhola, a mais bela é a Ilha Stromboli que abriga vulcão com o mesmo nome em atividade contínua e lugar do Vale dos Templos, sítio arqueológico incrivelmente preservado no tempo e exposição de uma das mais belas arquiteturas helênicas daquele período. Local de navegação dos maiores barcos da Antiguidade envoltos ao início do comércio internacional, diversificado nas redondezas de Concórdia e Agrigento, áreas ricas em vegetais, legumes e frutas dada a riqueza mineral do solo vulcânico. A mais abundante das especiarias, até hoje, a amêndoa, que, por meio da pasta - chamada antigamente de pasta real -, originou o delicioso Marzipan, tornando-se meio eficaz da Economia local, além de catálogo significativo de frutas nativas. Arqueólogos catalogam que nas ilhas Eólias viveram cerca de 200 mil habitantes entre os séculos VI e VIII a.C., a maioria de origem grega. As ilhas não são muito acessíveis devido às constantes manifestações vulcânicas, mas não empecilho a pesquisadores, geólogos e vulcanólogos... e muito menos aos homens da Antiguidade que atracavam imensos barcos de comércio, posteriormente o comércio internacional! 


\section{Referências}

ARISTÓTELES. A ética de Nicômaco. Tradução de Cássio M. Fonseca. São Paulo: Athena, 1940. (Biblioteca Clássica, v. 33).

. A política. Tradução de Nestor Silveira. São Paulo: Edipro, 2010. v. 11. (Coleção Folha: livros que mudaram o mundo).

BITTAR, Eduardo Carlos Bianca. A teoria aristotélica da Justiça. Revista da Faculdade de Direito da Universidade de São Paulo, São Paulo, v. 92, p. 53-73, jan./dez., 1997.

. Curso de filosofia aristotélica: leitura e interpretação do pensamento aristotélico. São Paulo: Editora Manole Ltda., 2003.

; ALMEIDA, Guilherme Assis de. Curso de filosofia do direito. São Paulo: Editora Atlas, 2001.

CAMPOS NETO, Antonio Augusto Machado de. O Confucionismo, Budismo, Taoismo e Cristianismo. O Direito chinês. Revista da Faculdade de Direito da Universidade de São Paulo, São Paulo, v.110, p. 67-94, jan./dez., 2015.

. O cristianismo. O direito canônico. Revista da Faculdade de Direito da Universidade de São Paulo, São Paulo, v. 105, p. 39-77, jan./dez., 2010.

. O cristianismo ortodoxo. O Direito Russo. Revista da Faculdade de Direito da Universidade de São Paulo, São Paulo, v. 109, p. 75-105, jan./dez., 2014.

. O hinduísmo. O direito hindu. O direito indiano. Revista da Faculdade de Direito da Universidade de São Paulo, São Paulo, v. 104, p. 71-111, jan./dez., 2009.

. O judaísmo. O direito talmúdico. Revista da Faculdade de Direito da Universidade de São Paulo, São Paulo, v.103, p. 27-67, jan./dez., 2008.

CICCO, Cláudio. Direito, cidadania e justiça. São Paulo: Editora Forense, 1985.

COÊLHO, Sacha Calmon Navarro. A história da mitologia judaico-cristã: uma teoria sobre as religiões reveladas servida por uma antologia comentada de autores seletos. São Paulo: Noeses, 2010 .

CONDÉ, Bertho. Roteiro de história da filosofia. São Paulo: Editora Piratininga, 1989.

CRETELLA JÚNIOR, José. Curso de filosofia do direito. 3. ed. Rio de Janeiro: Editora Forense, 1990.

DURANT, Will. A história da filosofia. Organização e redação de Bernadette Siqueira Abrão. São Paulo: Nova Cultural, 2009. (Coleção Os Pensadores).

FERRAZ JÚNIOR, Tércio Sampaio. Introdução ao estudo do direito: técnica, decisão, dominação. 2. ed. São Paulo: Atlas, 1986. 
FERREIRA, Aurélio Buarque de Holanda. Dicionário Aurélio da língua portuguesa. Rio de Janeiro: Editora Nova Fronteira, 2014.

GALVES, Carlos Nicolau. Manual de filosofia do direito. Rio de Janeiro: Editora Forense, 1995.

GARCÍA MORENTE, Manuel. Fundamentos de filosofia: lições preliminares. São Paulo: Editora Mestre Jou, 1980.

GUTHRIE, William Keith Chmabers. Os sofistas. Tradução de João Rezende Costa. São Paulo: Editora Paulus, 1995.

HILL, Jonathan. História do cristianismo. 1. ed. Tradução de Rachel Kapt Cunha, Juliana A. Saad e Marcos Capano, São Paulo: Editora Rosari, 2008.

KARDEC, Allan. O Livro dos espíritos. Tradução de José Herculano Pires. 10. ed. São Paulo: Editora FEESP, 2001.

. Obras póstumas. Tradução de João Teixeira de Paula. São Paulo: Editora Lake, 1995.

KRAUS, René. Sócrates, sua vida pública e particular. 2. ed. Tradução de Marina Guaspari. Rio de Janeiro: Editora Vecchi, 1961.

MARÍAS, Julián. Biografia da filosofia e ideia da metafísica. São Paulo: Livraria Duas Cidades, 1988.

. História da filosofia. Porto: Sousa \& Almeida Ltda., 1989.

MICHAELIS, Henriette. Illustrated dictionary. Rio de Janeiro: Editora Melhoramentos, 2010.

MONTORO, André Franco. Estudos de filosofia do direito. 2. ed. São Paulo: Editora Saraiva, 1995.

NAVARRO, Julia. A Bíblia de barro. Tradução de Luís Carlos Cabral. Rio de Janeiro: Editora Ediouro, 2006.

PADOVANI, Umberto; CASTAGNOLA, Luís. História da filosofia. São Paulo: Editora Companhia Melhoramentos, 1989.

PIRES, José Herculano. Astronautas do além. 3. ed. São Paulo: Editora Grupo Emmanuel, 1983. . Revisão do cristianismo. São Paulo: Editora Paidéia, 1990.

PLATÃO. Apologia de Sócrates. Tradução de Enrico Corvisieri. São Paulo: Editora Nova Cultural, 1999. (Coleção Os Pensadores).

. Platão. Apologia de Sócrates, o banquete e Fedro. Tradução de Edson Bini e Albertino Pinheiro. 1. ed. São Paulo: Folha de S. Paulo, 2010. v. 5. (Coleção Folha: livros que mudaram o mundo).

QUEIROZ, José Fleurí. Educação como direito e dever: a luz da filosofia e do direito natural. São Paulo: Mundo Jurídico, 2003. 
QUEIROZ, José Fleurí. Filosofia do direito. 'A justiça pura e completa'. Código de direito natural espírita. Projeto para aperfeiçoamento das leis civis e penais. São Paulo: Mundo Jurídico, 2006.

REALE, Miguel. Filosofia do direito. 17. ed. São Paulo: Saraiva, 1996.

SÃO MARCOS, Manoel P. Noções de história da filosofia. Apostila: $1^{\mathrm{o}}$ ano do curso de filosofia espírita: área de ensino. São Paulo: Editora Federação Espírita do Estado de São Paulo (FEESP), 1993.

WILKINSON, Philip. O livro ilustrado das religiões. O fascinante universo das crenças e doutrinas que acompanham o homem através dos tempos. São Paulo: Editora Publifolha, 2000. 
